\title{
Evaluation of ocean color and sea surface temperature sensors algorithms using in situ data: a case study of temporal and spatial variability on two northeast Atlantic seamounts
}

\author{
Ana Mendonça, ${ }^{\text {a,b }}$ Ana Martins, ${ }^{\text {a }}$ Miguel Figueiredo, ${ }^{\text {Ig }}$ Igor \\ Bashmachnikov $^{b}$, Andre Couto ${ }^{b}$, Virgine Lafon, ${ }^{b}$ and Javier Aristegui ${ }^{c}$ \\ a Universidade dos Açores, Departamento de Oceanografía e Pescas, Cais de Santa Cruz, \\ Horta, Acores, Portugal 9901-863 \\ amendonca@uac.pt; anamartins@uac.pt \\ ${ }^{\text {b }}$ Centro do IMAR da Universidade dos Acores, Departamento de Oceanografía e Pescas, \\ Horta, Portugal \\ olliegator@hortanet.com; adbc@portugalmail.com; vir_lafon@hotmail.com \\ igorb@uac.pt \\ ${ }^{\mathrm{c}}$ Universidad de Las Palmas de Gran Canaria, Facultad de Ciencias del Mar, Spain \\ jaristegui@dbio.ulpgc.es
}

\begin{abstract}
Main objectives of this paper are to evaluate SeaWiFS, MODIS, and AVHRR satellite imagery performances against in situ data around two Northeast Atlantic seamounts, Sedlo and Seine. The temporal and spatial variability of satellite-derived near-surface chlorophyll $a(\mathrm{Chl}$ a) and sea surface temperature (SST) is also analysed. SeaWiFS tends to show good accuracy with the in situ data for Sedlo seamount, while for Seine it tends to slightly overestimate the values. Oppositely, MODIS tends to underestimate Chl a for both seamounts. Match-up SST analyses show that MODIS underestimates the in situ values on Seine seamount. The best correlation was attained with AVHRR on Sedlo. Seasonal variations are clearly pronounced on Sedlo with typical spring and autumn Chl a blooms, while further to the south, on Seine, less intense blooms are registered, as expected. Higher/lower SST values are observed during summer/winter respectively, showing clear seasonal patterns. A time lag of about one month for the maximum SST heating/cooling from Sedlo to Seine is noted.
\end{abstract}

Keywords: Northeast Atlantic, seamounts, ocean color, sea surface temperature, temporal variability.

\section{INTRODUCTION}

The testing and evaluation of global algorithms applied to a regional scale play a growing importance in Satellite/Biological Oceanography. More and more satellite data are included in biological/ecological models and its essential to quantify the uncertainty of satellite data set e.g. time-series of Sea Surface Temperature (SST) and chlorophyll $a$ (Chl a) at regional to local scales. For primary production (PP) estimates, the output accuracy of the models is strongly dependent upon the accuracy of input products (e.g. satellite-derived Chl a and SST estimates). Mathematical analyses show that the most important input parameter influencing PP output model quality is the Chl a concentration [1,2]. Overestimations or underestimations of Chl a can lead to systematic miscalculation of PP estimates. Ref. 1 studied 24 different PP models and observed that if satellite-derived Chl a concentration was changed by a factor of four that was translated into a change of PP of about three times in all these models. Most PP models also use SST to quantify maximum photosynthetic rate and/or to characterize the 
environmental conditions experienced by the cells. Although of lesser importance, if satellitederived SST values are used as input data, models sensitivity analyses show that the dependence on SST, especially with regards to the formulation of the maximum photosynthetic rate, seems to impact the models, regardless of model complexity $[1,2]$.

Furthermore, at regional scale, satellite-derived SST and Chla a have been used extensively in oceanographic studies to, among others quantify processes responsible for phytoplankton and surface temperature spatial and temporal variability, to describe current flow and recirculation, ocean surface currents, and vortices detection [3-11]. Therefore, it is useful to develop an understanding of satellite data limitations and quantify the uncertainty of the algorithms used in global estimates applied to regional and/or local scales. Comparisons between in situ and remotely-sensed $\mathrm{Chl}$ a have been performed in the Atlantic ocean. Some authors [12,13] compared SeaWiFS estimations with field data and showed that this sensor overestimates in situ values for the Atlantic ocean while others [14] found good agreement between SeaWiFS and in situ data e.g. for a region north of Canary Islands. One limitation, referred by more than one author [e.g. 12] is the low number of in situ sampling stations existing at the eastern portion of the North Central Atlantic (where one of our regions of study is located). Also, Ref.15 recognize that only about $5 \%$ of Chl a measurements from SeaBASS came from open ocean.. Other authors [16] call the attention for the digitization-noise errors on SeaWiFS ocean color estimates. Simulation results show that for typical atmospheric conditions in open ocean oligotrophic (maritime aerosols) at a particular pixel the errors in the data products can be as large as about $65 \%$ for $\mathrm{Chl}$ a concentrations for oligotrophic waters. Additionally, the need of high accuracy in the SST measurements, better than $1^{\circ} \mathrm{C}$, was recognized by several authors [17-19]. For example, SSTs derived through the MCSST algorithm [20,21] agree well with in situ SSTs with root mean square errors of less than 0.7 ${ }^{\circ} \mathrm{C}[17,22-24]$. Sea surface temperature validation efforts were made for the Atlantic Ocean, including at regional scales e.g. Canary Islands-Azores-Gibraltar, using different algorithms $[18,19]$. The comparisons between co-located SST pixel values and in situ measurements for the Azores region showed good accuracy [15].

This paper concentrates on evaluation of the OC/SST algorithms performance for Atlantic oligotrophic waters, using as case study two isolated Northeast Atlantic seamounts: Sedlo (N of the Azores archipelago) and Seine (NE of the Madeira archipelago). Seamounts ecosystems are spatially separated from the continental shelves, sometimes several hundreds or thousands of miles, and located between the deep-sea and the euphotic zones. Our knowledge of seamounts ecosystem dynamics is still limited. There are some works combining phytoplankton biology with physical oceanography (e.g 24; 25; 26; 27 and 31), but integration of the biological, biogeochemical and physical information yet has not been performed. Within this context a three years European multidisciplinary project (EVK3-200100152: OASIS - "OceAnic Seamounts: an Integrated Study") was implemented with the principal aim to yield an advanced understanding of coupled physical-biological processes characterizing seamount ecosystems. Inside the framework of this project, this paper addresses the problem of ocean color sensor accuracy (SeaWiFS vs. MODIS) and Chl-a algorithm performance at temporal and spatial scales adequate to capture the Chl-a patches in the vicinity of the seamounts. The SST sensor accuracy (MODIS and NOAA/AVHRR) is also addressed. Specifically we aim to understand the performance of the algorithms at the seamounts scale, serving validation goals and indirectly contributing to improve satellite primary production estimates at regional scale approaching more realistic estimates. A second goal of the paper is to analyze the seasonal and interannual variability of Chl-a and SST at each seamount and two additional sites, presumably removed from the influence of the seamounts. In the first case, time series of AVHRR (SST, using the MCSST algorithm [30]), SeaWiFS (OC, using the OC4v4 algorithm, [31] and MODIS (OC, using the OC3M algorithm, [31]) and MODIS (SST, using the NLSST algorithm, [32] imagery are used with concurrent in situ measurements carried out during the OASIS research cruises and other 
projects cruises (e.g. FISHOR) to test the accuracy and the robustness of the near-surface satellite derived Chl a and SST measurements. In the second case, the temporal (monthly to seasonal time-scale variation) and spatial variability of the OC data (SeaWiFS-1999 to 2002 and MODIS-2003 to 2006) and the SST data (AVHRR-2001 to 2005) obtained for the Sedlo and Seine regions are statistically analysed. Two additional regions (outside of the seamounts ranges) were also defined and compared with the two seamount regions.

\section{METHODS}

\subsection{Study area}

Sedlo and Seine seamounts are both isolated features, but differ in their geographic localization, topography, summit depths, physical and hydrographic characteristics (Fig. 1).

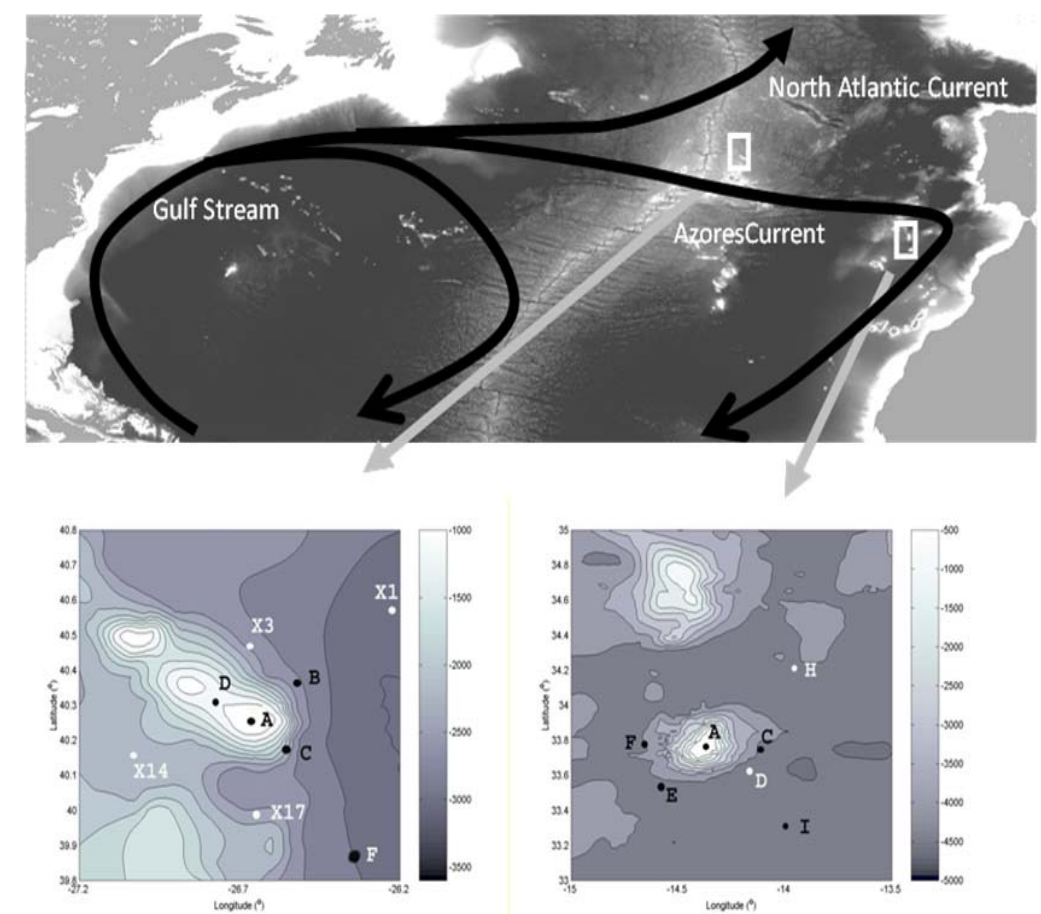

Fig. 1. Top: location of OASIS NE Atlantic seamounts. Left: Sedlo seamount with position of in situ sampling stations (cruises R/V METEOR M60/1 and RRS DISCOVERY 282). Right: Seine seamount with position of in situ sampling stations (cruises R/V POSEIDON 295; R/V METEOR M60/1; R/V POSEIDON 309 and RRS DISCOVERY 282.

Nevertheless, they are considered in the same biogeochemical North Atlantic Subtropical Gyral Province (NAST) defined by the Ref. 33, Sedlo is situated at a more temperate zone at the north-eastern border of the Azores rise, in the vicinity of the Mid-Atlantic Ridge (MAR) while Seine is in a more tropical region well inside the North Atlantic subtropical gyre . The first is placed north of the Azores archipelago at about $41^{\circ}-40^{\circ} \mathrm{N} ; 26^{\circ}-27^{\circ} \mathrm{W}$ and the latter is located northeast of Madeira archipelago at about $34^{\circ}-33^{\circ} \mathrm{N} ; 14^{\circ}-15^{\circ} \mathrm{W}$. Sedlo is a chain 
seamount composed of three summits, below the winter-mixed layer, with the shallowest at $760 \mathrm{~m}$ depth. Seine is a cone-shaped seamount with a single summit at $175 \mathrm{~m}$ depth, below the euphotic zone, but reaching into the winter-mixed layer. The upper flanks of both seamounts are located in the subtropical North Atlantic intermediate waters with Mediterranean water (MW) impinging close to the summit of Sedlo and at mid flanks of Seine [34]. Seine is in the area of direct influence of the eastward Azores current (AzC), being located just south of its yearly mean position [35].

Two seamount areas were chosen for this research: 1) Sedlo seamount $\left(42^{\circ}-39^{\circ} \mathrm{N} ; 25^{\circ}\right.$ $\left.28^{\circ} \mathrm{W}\right)$; and 2) Seine seamount $\left(35^{\circ}-32^{\circ} \mathrm{N} ; 13^{\circ}-16^{\circ} \mathrm{W}\right)$. Furthermore, two additional areas were chosen for comparison with the two seamount areas: one localized between Seine and Sedlo, northwest of Seine, named NW_Seine $\left(39^{\circ}-36^{\circ} \mathrm{N} ; 19^{\circ}-22^{\circ} \mathrm{W}\right)$ and the other localized at the same latitude as Seine named W_Seine $\left(35^{\circ}-32^{\circ} \mathrm{N} ; 19^{\circ}-22^{\circ} \mathrm{W}\right)$.

\subsection{Satellite data}

\subsubsection{SeaWiFS and AVHRR}

SeaWiFS and AVHRR data (both at 1.1. km resolution) were obtained at the HAZO HRPT station located in the Azores as described by the Ref. 36 and processed at the Centre of IMAR - University of the Azores, Department of Oceanography and Fisheries (IMAR-DOP/UAç). The processing and mapping is automated within the HAZO system [37]. AVHRR data is semi-automatically processed up to Level 3 (SST in ${ }^{\circ} \mathrm{C}$ ) using the software Terascan and the MCSST algorithm. SeaWiFS data is automatically processed up to Level 2-map (L2-map standard NASA format, i.e. Chl a in $\mathrm{mg} \mathrm{m}^{-3}$ ) using the programs Qt2cwlz (converts encrypted raw data into encrypted level 0 and was developed by Quorum and IMAR-DOP/UAz), OGP (decrypts encrypted level 0 and was developed by Orbview), Swl01 (converts SeaWiFS level 0 files, to level 1a in Hierarchical Data Format (HDF) and software SeaDAS 5.2 with l2gen5.8.3 (using OC4v4 algorithm), both programs developed by NASA. SeaWiFS images from other HRPT NASA authorized stations were also used. Imagery averages, standard deviations and coefficient of variation were also computed. The SeaWiFS data used was based on the OBPG time series prior to December 2009 re-processing, as a result there can be some errors in the data and findings.

The Sedlo and Seine seamount have the same area 401 x 300 pixels. The resultant daily geophysical data (OC and SST) were monthly averaged and the minimum, maximum, standard deviation (STD), and coefficient of variation (CV) (not shown) were obtained. Prior to these statistical analyses, Chl a values below $0.01 \mathrm{mg} \mathrm{m}^{-3}$ and above $7 \mathrm{mg} \mathrm{m}^{-3}$ were excluded from further analysis. This is related with the in situ Chla data for the region, collected since 2002 (Fig. 2 - top and middle panel). This figure shows, until now, values always lower than $7 \mathrm{mg} \mathrm{m}^{-3}$. On the other hand, only SST values above $10{ }^{\circ} \mathrm{C}$ and below $30^{\circ} \mathrm{C}$ were used in the analyses to avoid "false" low water temperature values due to pixel cloud contamination. In situ monthly mean surface temperatures at the Horta port (Azores) from August 1993 to October 2006 are shown in bottom panel (cf. Fig.2). 


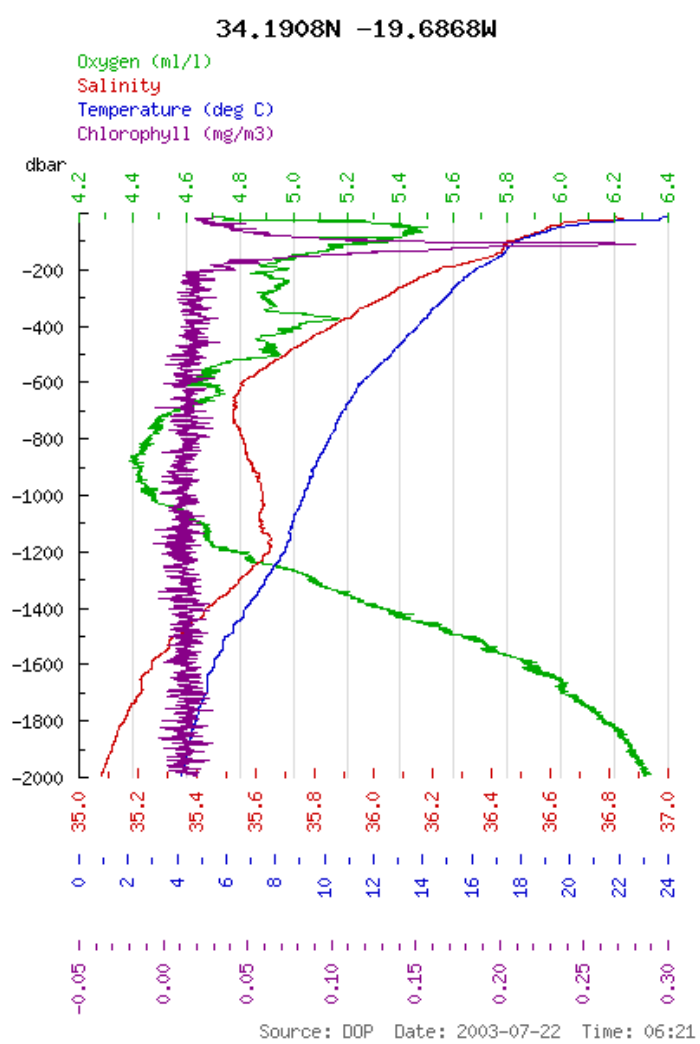

(a)

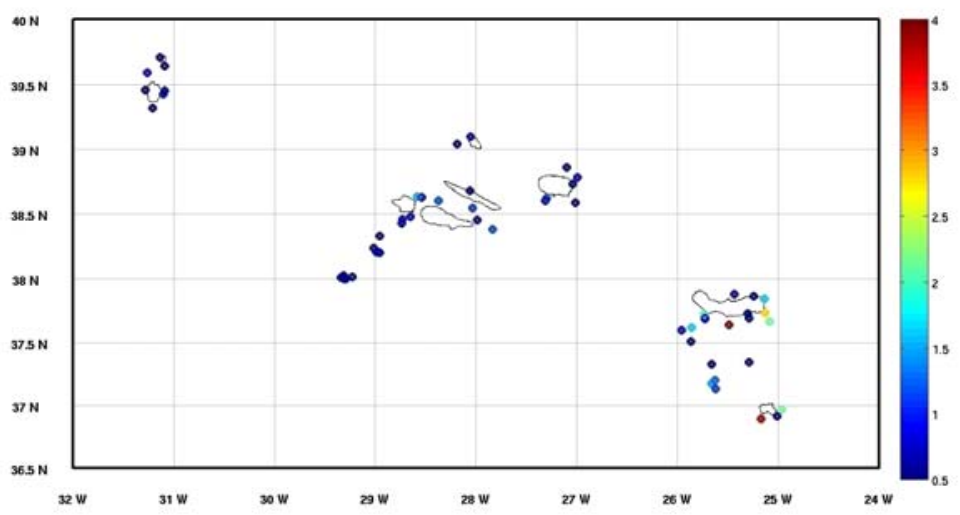

(b) 


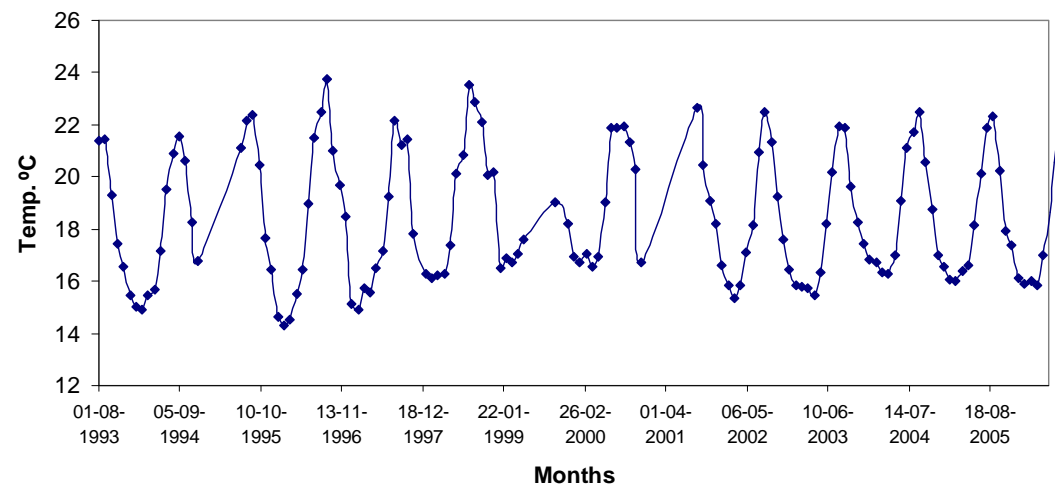

(c)

Fig. 2. (a) represents CTD/fluorometer profiles from the Azores region, (available from site http://oceano.horta.uac.pt/azodc/oceatlas.php). The profiles show typical range of Chl a values for the region. (b) shows range of Chl a values, measured with ship fluorometer during the cruises of 2002-2004 near the Azores islands. The maximum value obtained was around $4 \mathrm{mg} / \mathrm{m}^{-3}$. (c) shows in situ monthly mean surface temperatures at the Horta port from August 1993 to October 2006 (obtained from http://oceano.horta.uac.pt/detra/).

\subsubsection{MODIS}

MODIS (aboard Aqua satellite) $1.1 \mathrm{~km}$ resolution Level $2 \mathrm{Chl}$ a product, derived from the OC3M algorithm and SST product derived from NLSST algorithm are regularly obtained from the Ocean Color Level 1/2 browser (http://oceancolor.gsfc.nasa.gov/cgi/browse.pl) for the Azores region. These images are mapped at IMAR-DOP/UAç (Level2-map) with SeaDAS 5.2 with l2gen5.8.3 developed by NASA. The download and mapping process is also automated within the HAZO system [37]. Imagery averages, standard deviations and coefficient of variation were also computed. The MODIS-Aqua data used was based on the OBPG time series prior to the expected reprocessing during 2010. As a result there can be some errors in the data and findings.

In this study, MODIS data were used in the satellite match-up analyses with in situ data and to study seasonal and inter-annual variability between 2003 and 2006. Chlorophyll a and SST threshold limits imposed on MODIS data were similar to the SeaWiFS and AVHRR ones.

\subsection{In situ data}

\subsubsection{Chlorophyll $a$}

SeaWiFS and MODIS satellite validation at each seamount local scale was made by comparing the OC4v4 and OC3M algorithms estimates with concurrent in situ Chl a observations.

The in situ data were obtained from a total of four OASIS cruises. Seine was sampled during March 2003 (cruise R/V POSEIDON 295), November 2003 (cruise R/V METEOR M60/1), March/April 2004 (cruise R/V POSEIDON 309), and July 2004 (cruise RRS DISCOVERY 282), while Sedlo was sampled during November 2003 (cruise R/V METEOR M60/1) and July 2004 (cruise RRS DISCOVERY 282). As described by Ref. 38, water samples for the determination of Chl a were obtained at each station at the surface, $25 \mathrm{~m}, 50 \mathrm{~m}$, 
$75 \mathrm{~m}, 100 \mathrm{~m}$ and $150 \mathrm{~m}$. Chl a was estimated fluorometrically. Seawater samples $(1 \mathrm{~L})$ were filtered through Whatman GF/F fiber-glass filters. The filters were stored in liquid nitrogen until assayed. Pigments were extracted in cold acetone $(90 \% \mathrm{v} / \mathrm{v})$ for $24 \mathrm{~h}$. Fluorescence before and after acidification was measured by means of a Turner Designs bench fluorometer, previously calibrated with pure chlorophyll a (Sigma Co.). For this comparison in situ data from seven stations at Sedlo seamount and nine stations at Seine seamount were used (cf. Fig. 1). Satellite measurements represent a water-column weighted average [39-41], while in situ measurements usually come from discrete depths. In our case, in situ Chl a concentrations obtained from: 1) a surface measurement and 2) a weighted average depth-integrated concentration estimated until $25 \mathrm{~m}$ depth $\left(\mathrm{C}_{\text {situ }}\right)$ were compared with coincident satellite data $\left(\mathrm{C}_{\mathrm{sat}}\right)$. One PAR profile (with indication of first optical depth, $\mathrm{Z}_{90}$, about $35 \mathrm{~m}$ ) obtained during an OASIS cruise for the Seine seamount is presented in Figure 3. Our data for the region show the Deep Chlorophyll Maximum (DCM) to be located at about $75 \mathrm{~m}$ depth, depending on location and season, reaching sometimes $100 \mathrm{~m}$ depth.

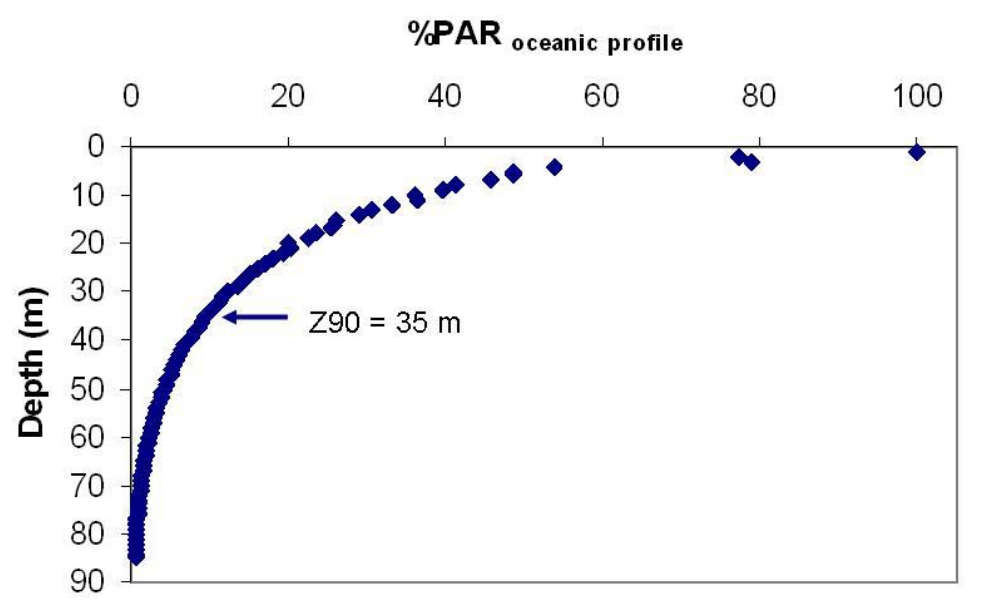

Fig. 3. PAR profile from Seine seamount during March/April 2004 (cruise R/V POSEIDON 309) obtained using a PNF300 instrument. The Z90 found is $35 \mathrm{~m}$.

\subsubsection{Surface temperature}

The satellite-derived SST values were compared with the in situ surface temperature measurements obtained within the framework of the projects OASIS and FISHOR (Exploratory Fishing of the Orange Roughy (Hoplostethus atlanticus) in the Azores). In situ temperatures were measured using onboard thermometers mounted on the keel, and according to the vessel design, at a depth of approximately 3 to 4 meters. For this comparison, the in situ data for Seine were obtained during March 2003 (R/V POSEIDON 295) and March/April 2004 (R/V POSEIDON 309). For Sedlo, the in situ data were collected during May to August 
2001 and December 2001 to January 2002 (FISHOR project), and during July, August and October 2003 (OASIS project).

Satellites measure the skin SST while the in situ data in this study is bulk (anywhere from $20 \mathrm{~cm}$ to about 3-4 m depth) SST. Even so, Ref. 17 found fairly good matching between the AVHRR derived SST values and in situ temperature measurements, taken between $20 \mathrm{~cm}$ and $5 \mathrm{~m}$ depth (bulk SST) for the Azores region. Therefore, the temperature data measured at these depths were considered valid for the match-up-analyses.

Furthermore, monthly mean temperature values for the Azores region (cf. Fig. 2) typically show surface values above $13.5^{\circ} \mathrm{C}$. Hence, temperatures below this value were considered invalid for the purpose of the match-up analyses, as they most probably reflect atmospheric (clouds) correction problems.

\subsubsection{Match-up analyses}

A consistent procedure was defined to validate concurrent data with match-up analysis using SatCmp [43] and SeaDAS. Given the date, time and location (i.e. latitude/longitude) for the $\mathrm{C}_{\text {situ }}$, the SatCmp's algorithm first tries to find the image with the least time difference within 12 hours around the sampling time, and then it tries to find a valid pixel for the location which constitute the match-up $\left(\mathrm{C}_{\text {situ, }} \mathrm{C}_{\text {sat }}\right)$. If a valid satellite pixel is not found, the algorithm tries to find valid pixels within a $3 \times 3$ window centered at the location of each station $[15,43]$ where $C_{\text {situ }}$ data is available and calculates an average $C_{\text {sat }}$ value. If there are no valid pixels within the spatial $3 \times 3$ window. or there are no images for that day, the algorithm tries to find spatially coincident $\mathrm{C}_{\text {sat }}$ estimates within 1 day (and up to the maximum of 3 days) of the $\mathrm{C}_{\text {situ }}$ day of measurement. The same procedure (spatial $3 \times 3$ window) is applied in these last cases. To validate the satellite-derived SST the same procedure was used, in this case the $\mathrm{C}_{\text {situ }}$ was defined as the in situ surface temperature.

\section{RESULTS}

\subsection{Satellite match-up analyses}

\subsubsection{SeaWiFS (OC4v4) and MODIS (OC3M) versus in situ Chl a}

A total of 18 (Sedlo) and 27 (Seine) match-up data points per satellite were obtained for the comparative analysis (Table 1).These data cover a range of $\mathrm{C}_{\text {situ }}$ values from 0.06 (surface, Seine) to $0.44 \mathrm{mg} \mathrm{m}^{-2}$ (surface, Seine). A significant prevalence of in situ Chl a values typical of oligotrophic regimes is observed (see also Ref. 38 for Chl a profile values).

Table 1. Number of match-up data points (per OC satellites) obtained from the analysis of concurrent SeaWiFS (OC4v4) and/or MODIS (OC3M) versus in situ Chl a data.

\begin{tabular}{cccc}
\hline & Surface vs. & 25 m vs. & Total p/ \\
Location & OC satellites & OC satellites & OC satellites \\
\hline Sedlo & 9 & 9 & 18 \\
Seine & 15 & 12 & 27 \\
Total p/ & & & \\
OC satellites & 24 & 21 & 45 \\
\hline
\end{tabular}


The results for the match-up analysis for the different depths contains information about the percent error $\left(\% \mathrm{E}_{\text {sat }}\right)$ defined by the Ref. 43 (Csat is the satellite estimate) as:

$$
\% E_{\text {sat }}=100\left[\frac{C_{\text {situ }}-C_{\text {sat }}}{C_{\text {situ }}}\right]
$$

Statistical analyses of the satellite match-up for Sedlo and Seine (all-together) (Table 2) show low correlation coefficients for OC4v4. On the other hand, OC3M shows a very good and significant correlation with in situ data for both seamounts. The OC3M exhibits the best statistical performance between the two tested algorithms being the mean error avg(\%Esat) less than the 35\% required by NASA (cf. Table 2). On the other hand, the OC4v4 algorithm mean error avg(\%Esat) is higher than this required value.

Table 2. Comparative statistical analyses between the SeaWiFS/OC4v4 algorithm or MODIS/OC3M algorithm (Csat) with in situ chlorophyll a measurements $\left(\mathrm{C}_{\text {situ }}\right)$ obtained for both Sedlo and Seine seamounts. The \%Esat is obtained using Eq. (1). Min(\%Esat), avg(\%Esat), max(\%Esat) and std(\%Esat) represent the minimum, average, maximum, and the standard deviation of \%Esat, respectively. The correlation coefficient is given by $\mathrm{r}$. The significance level (p) calculated for each correlation is also given ( $\mathrm{p}<0,05, \mathrm{p}<0.01$ and ns: not significant).

\begin{tabular}{cccccccc}
\hline Algorithm & Depth & min (\%Esat) & avg (\%Esat) & max(\%Esat) & std(\%Esat) & r & p \\
\hline OC4v4 & surface & -873 & -67 & 83 & 193 & 0.121 & $\mathrm{~ns}$ \\
OC4v4 & $25 \mathrm{~m}$ & -226 & -39 & 42 & 83 & 0.188 & $\mathrm{~ns}$ \\
OC3M & surface & -40 & 18 & 63 & 30 & 0.715 & $<0,01$ \\
OC3M & 25m & -24 & 23 & 63 & 25 & 0.730 & $<0,01$ \\
\hline
\end{tabular}

Our results show that SeaWiFS tends to show good accuracy with the in situ data for Sedlo seamount while for Seine it tends to overestimate. MODIS tends to underestimate the in situ values (cf. Table 2, Figs. 4 and 5). For both seamounts a systematic increase in MODIS underestimation is found with increasing $\mathrm{Chl}$ a in situ concentrations (cf. Figs. 4 and 5). The same is not as evident with SeaWiFS data (cf. Figs. 4 and 5). These scatter plots also show that OC4v4 underestimates around $50 \%$ but around $25 \%$ gives similar in situ values for Sedlo while for Seine overestimates around $70 \%$ and only around $4 \%$ are similar in situ values. The OC3M underestimates around $72 \%$ for both seamounts. At very low in situ Chl a values both sensors tend to show similar scatter plot patterns. 


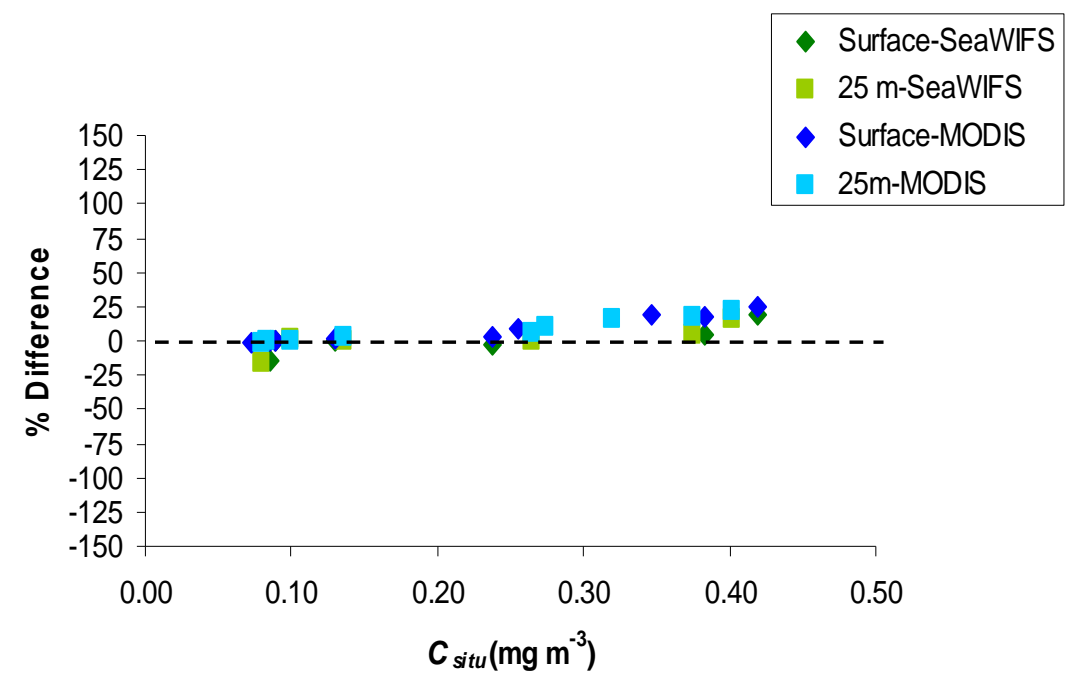

Fig. 4. Sedlo seamount. Percentage differences between in situ Chl a data (at surface and $25 \mathrm{~m}$ ) and satellite derived Chl a (\%difference=(Csitu-Csat)*100). SeaWiFS derived $\mathrm{Chl}$ a represented with green color and MODIS derived Chl a represented with blue color. Percentage values above zero represent satellite underestimation.

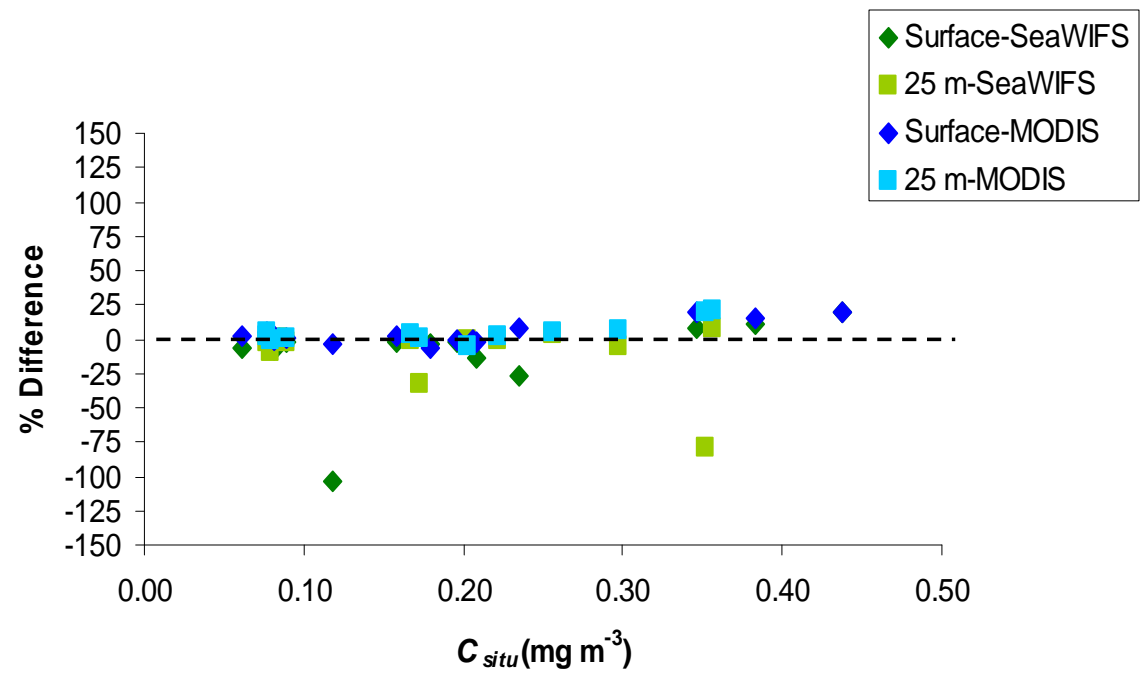

Fig. 5. Seine seamount. Percentage differences between in situ Chl a data (at surface and $25 \mathrm{~m}$ ) and satellite derived Chl a (\%difference $=($ Csitu-Csat)*100). SeaWiFS derived Chl a represented with green color and MODIS derived Chl a represented with blue color. Percentage values above zero represent satellite underestimation. 


\subsubsection{AVHRR-MCSST and MODIS-NLSST versus in situ surface temperature}

After the selection procedure outlined in sections 2.2.1 and 2.3.2, 159 (in situ Sedlo surface temperature vs AVHRR-derived SST), 38 (in situ Seine surface temperature vs AVHRRderived SST) and 38 (in situ Seine surface temperature vs MODIS-derived SST) match-up points were obtained for comparative analyses (Table 3). For MODIS-SST it was not possible to find mach-up points for Sedlo region.

Table 3. Number of match-up data points (per SST satellites) obtained from the analysis of concurrent AVHRR (MCSST) and/or MODIS (NLSST) versus in situ surface temperature data.

\begin{tabular}{cccc}
\hline Location & $\begin{array}{c}\text { Surface vs. } \\
\text { AVHRR } \\
\text { (MCSST) }\end{array}$ & $\begin{array}{c}\text { Surface vs. } \\
\text { MODIS } \\
\text { (NLSST) }\end{array}$ & Total \\
\hline Sedlo & 159 & 0 & 159 \\
Seine & 23 & 34 & 57 \\
\hline
\end{tabular}

Statistical analyses of the satellite match-up for Sedlo (Table 4) show highly significant correlation between AVHRR-SST and in situ values. The mean error avg(\%Esat) is about 0.9 $\%$.On the other hand, in Seine AVHRR- and MODIS-derived SST values show very low correlation with in situ values. Nevertheless, for this seamount the mean error avg (\%Esat) is about $0.6 \%$ for AVHRR-SST and $6.6 \%$ for MODIS-SST.

Table 4. Comparative statistical analyses between the AVHRR/MCSST or MODIS/NLSST with in situ temperature measurements from Seine. Same analyses are made between AVHRR/MCSST and Sedlo in situ temperatures. The \%Esat is obtained using Eq. (1). Min(\%Esat), avg(\%Esat), max(\%Esat) and std(\%Esat) represent the minimum, average, maximum, and the standard deviation of \%Esat, respectively. The correlation coefficients are given by $r$.The significance level (p) calculated for each correlation is also given $(\mathrm{p}<0.05, \mathrm{p}<0.01$ and ns: not significant).

\begin{tabular}{|c|c|c|c|c|c|c|c|c|}
\hline$\overline{\text { Seamount }}$ & Sensor & Algorithm & min (\%Esat) & avg (\%Esat) & $\max (\%$ Esat) & std(\%Esat) & $\bar{r}$ & $p$ \\
\hline Seine & AVHRR & MCSST & $-8,2$ & 0,1 & $-2,7$ & 4,9 & 0,248 & ns \\
\hline Seine & MODIS & NLSST & $-2,7$ & 6,7 & 20,1 & 6,7 & 0,189 & ns \\
\hline Sedlo & AVHRR & MCSST & $-7,5$ & 1,1 & 29,0 & 5,8 & 0,829 & $<0,01$ \\
\hline
\end{tabular}

Our results show that AVHRR/MCSST slightly underestimates Sedlo in situ values (Fig. 6), principally at high in situ temperatures, while it overestimates Seine in situ ones (Fig. 7). These different results can be related with the low match-up data points found for Seine, making it less representative of the actual temperature range in the area. On the other hand, MODIS/NLSST clearly underestimates around 97\% Seine in situ surface temperature values showing very low accuracy at high temperatures. 


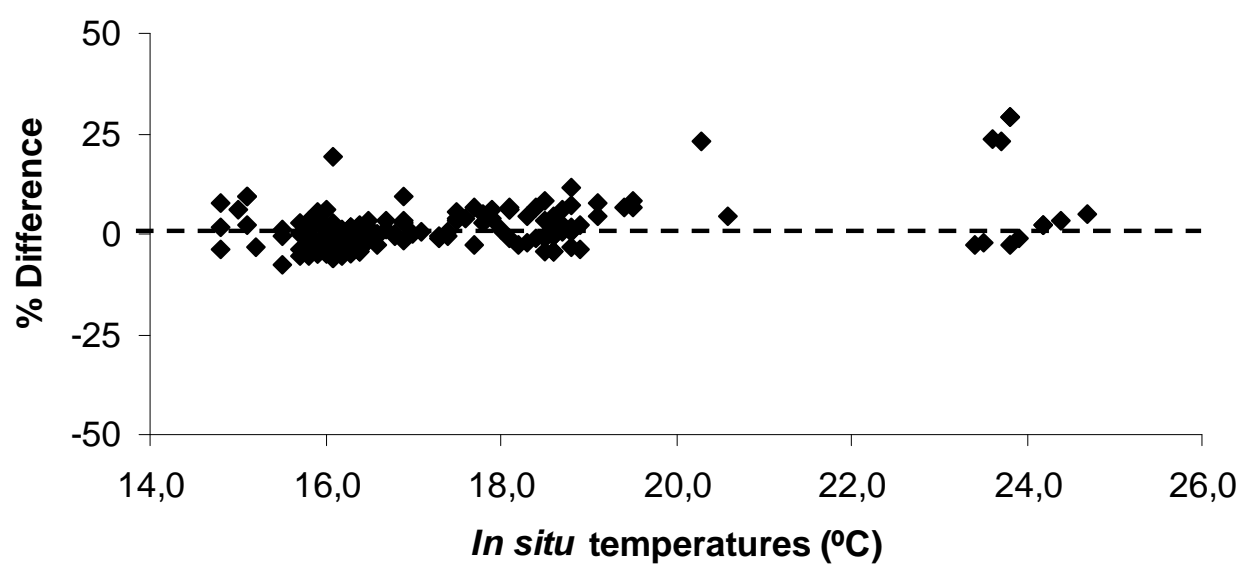

Fig. 6. Sedlo seamount. Percentage differences between in situ surface temperatures and AVHRR/MCSST ones as a function of in situ temperature. Percentage values above zero represent satellite underestimation.

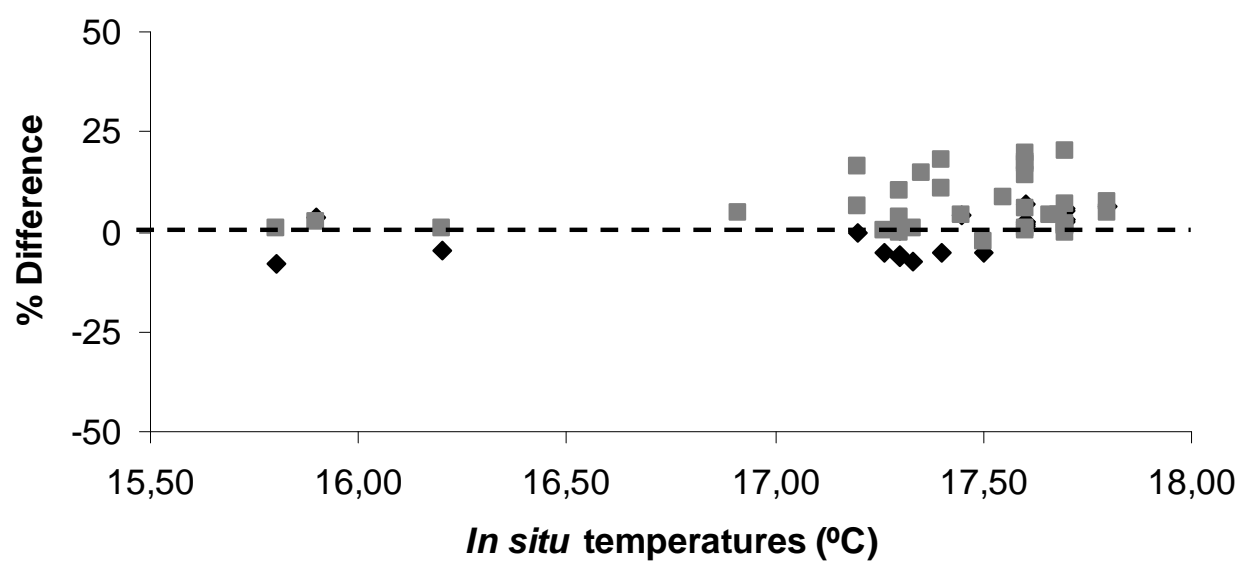

Fig 7. Seine seamount. Percentage differences between in situ surface temperatures data and AVHRR/MCSST (in black) and MODIS/LW-SST (in grey) as a function of in situ temperature. Percentage values above zero represent satellite underestimation.

\subsection{Seasonal and inter-annual variability}

\subsubsection{SeaWiFS and MODIS -derived Chl a concentration}

The SeaWiFS (years 1999 to 2002) and MODIS (2003 to 2006) monthly means obtained for Seine W_Seine, NW_Seine and Sedlo areas, are presented in Fig. 8. Despite the differences between the two sensors (see previous section), the general trends are the same and as one 
sensor completes the other, in terms of year coverage, we use both sensors to analyse the Chl a seasonal and inter-annual variability in the areas of study. In general the maximum and minimum Chl a monthly values are found on SeaWiFS and MODIS averages, respectively with Chl a monthly means that range approximately between $0.06 \mathrm{mg} \mathrm{m}^{-3}$ (September 2003, 2004 and 2006, MODIS) and $0.89 \mathrm{mg} \mathrm{m}^{-3}$ (April 2002, SeaWiFS).

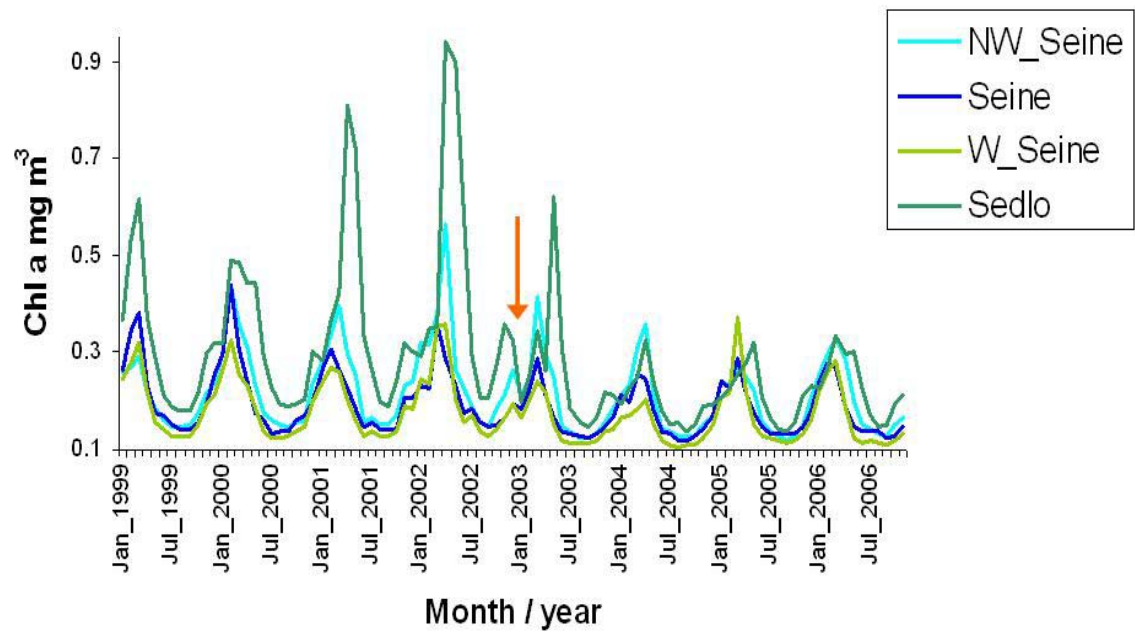

Fig. 8. SeaWiFS monthly Chl a means obtained for the years 1999 to 2002 for the northwest Seine (NW_Seine), Seine, west of Seine (W_Seine) and Sedlo. After January 2003 (see orange arrow) until 2006 the monthly Chl a means are MODIS derived.

In general, seasonal variation presents increasing values between October and April/May and decreasing values are registered from June to September (Fig. 9, cf. Fig. 8). Typical midlatitude spring $\mathrm{Chl}$ a blooms are observed in Sedlo on both SeaWiFS and MODIS means. Both (SeaWiFS and MODIS) monthly means show quite well a transition in latitude among the four regions with higher Chl a means in Sedlo, followed by NW_Seine, Seine, and W_Seine areas. Both sensors results, suggest strong inter-annual mean Chl a variability in all four regions. 


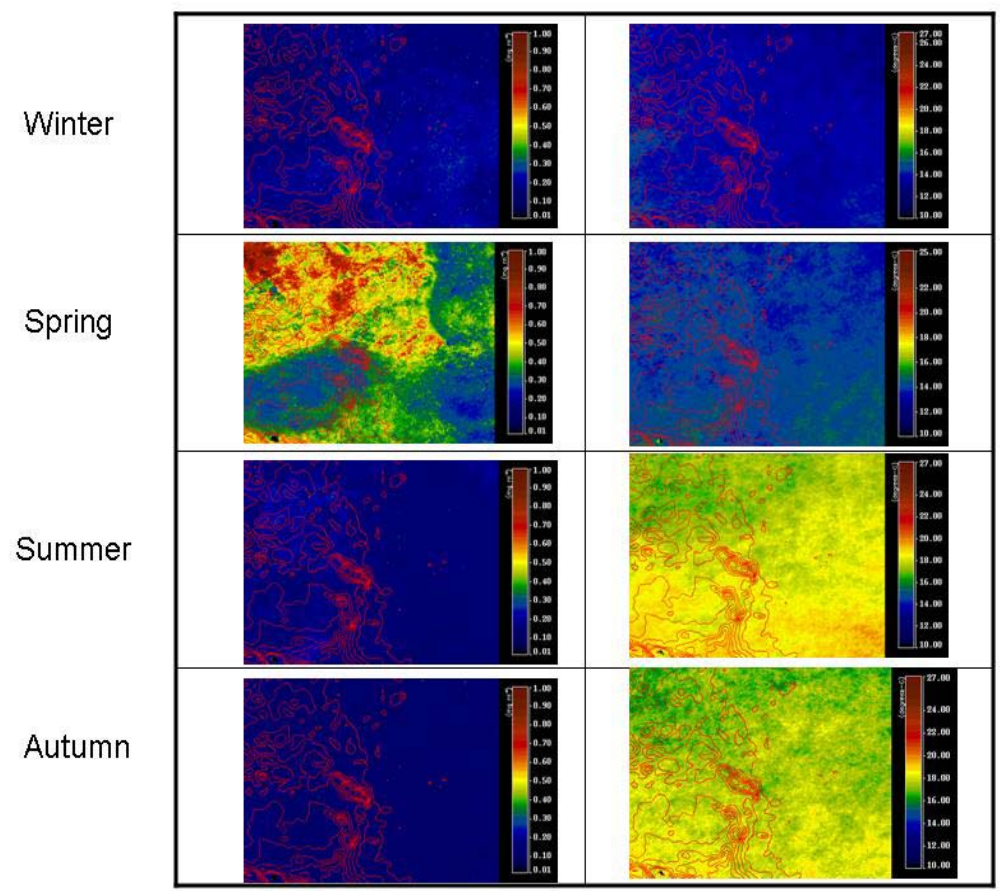

Fig. 9. MODIS OC (Chl a in $\mathrm{mg} \mathrm{m}^{-3}$ ) (left) and MODIS SST (in ${ }^{\circ} \mathrm{C}$ ) (right) seasonal means for winter (2002/2003), and spring, summer and autumn (2003) obtained for Sedlo seamount. The four oceanographic seasons are defined by the Ref. 11 .

On Seine seamount, increasing $\mathrm{Chl}$ a monthly averages are generally, found between November and March/April and decreasing values are registered between May and October, with the lowest values observed during summertime (Fig. 10). In this case, the spring bloom is not as evident. In fact, and contrary to what was observed in Sedlo, there are no typical blooms in Seine. Sometimes, a "spring bloom" is visible (e.g. March 2003), other times, some increase in average Chl a is observed during winter rather than in autumn (e.g. February 2000). When this peak is observed it is of low magnitude and is observed during winter time rather than in autumn. The 7-year Seine Chl a monthly means varies approximately between $0.06 \mathrm{mg} \mathrm{m}^{-3}$ in September 2004 (MODIS) to $0.39 \mathrm{mg} \mathrm{m}^{-3}$ in February 2000 (SeaWiFS). The W_Seine area monthly values do not change significantly from the Seine ones. However, in March 2005 and among the four regions of study, the highest monthly Chl $a$ average is found on the W-Seine region (0.32 $\mathrm{mg} \mathrm{m}^{-3}$ ) (cf. Fig. 8). 


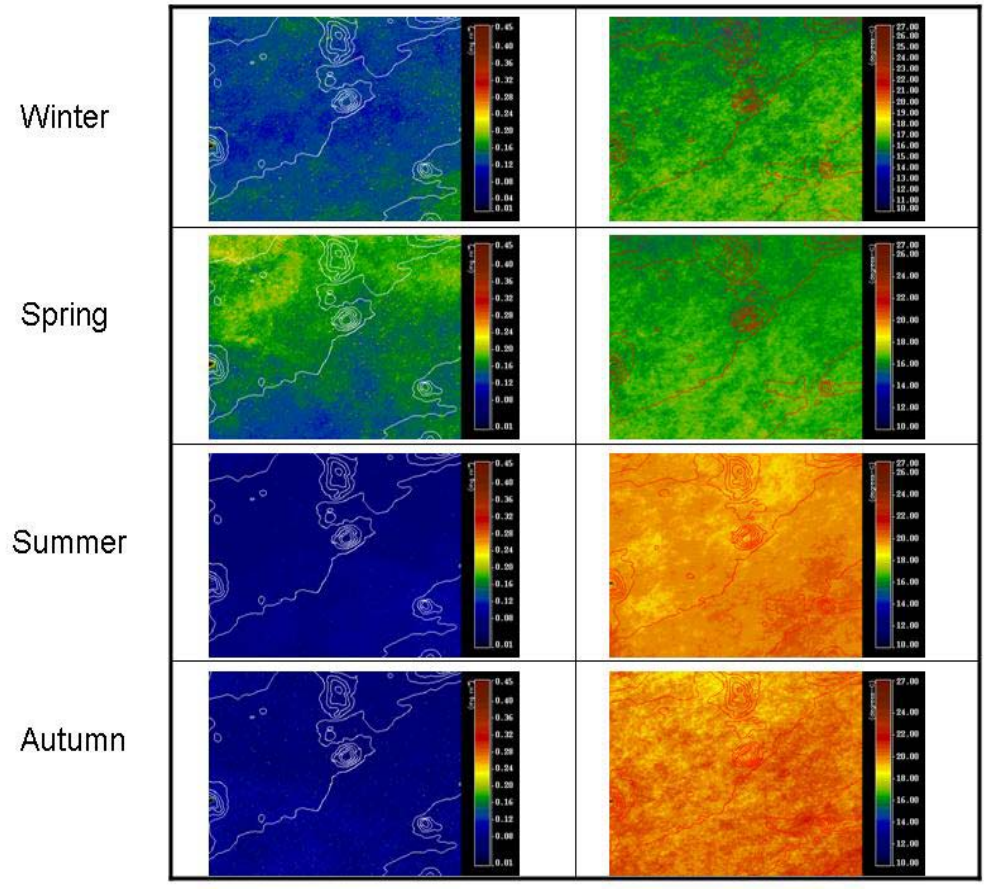

Fig. 10. MODIS OC (Chl a in $\mathrm{mg} \mathrm{m}^{-3}$ ) (left) and MODIS SST (in ${ }^{\circ} \mathrm{C}$ ) (right) seasonal means for winter (2002/2003), and spring, summer and autumn (2003) obtained for Seine seamount. The four oceanographic seasons are defined by the Ref. 11.

Inter-annual variability is observed on all four regions, for both SeaWiFS and MODISderived Chl a monthly averages (Fig. 11). The results obtained from both sensors for concurrent years (2002 to 2004) clearly show that SeaWiFS means are highest and more variable than MODIS ones. In fact, on all four areas, the largest inter-annual variability is observed on the SeaWiFS-derived Chl a monthly means. In general, MODIS monthly means follow the same pattern as the SeaWiFS ones however with low values. Sedlo monthly means standalone from all other three regions means. Nevertheless, both sensors results indicate that Sedlo has in average the highest annual mean, followed by the NW_Seine, Seine, and W_Seine areas, clearly suggesting a latitudinal effect in the average distribution of Chl a. For all the four region SeaWiFS overestimate the Chl a values in relation to MODIS ones (Fig. 12). 


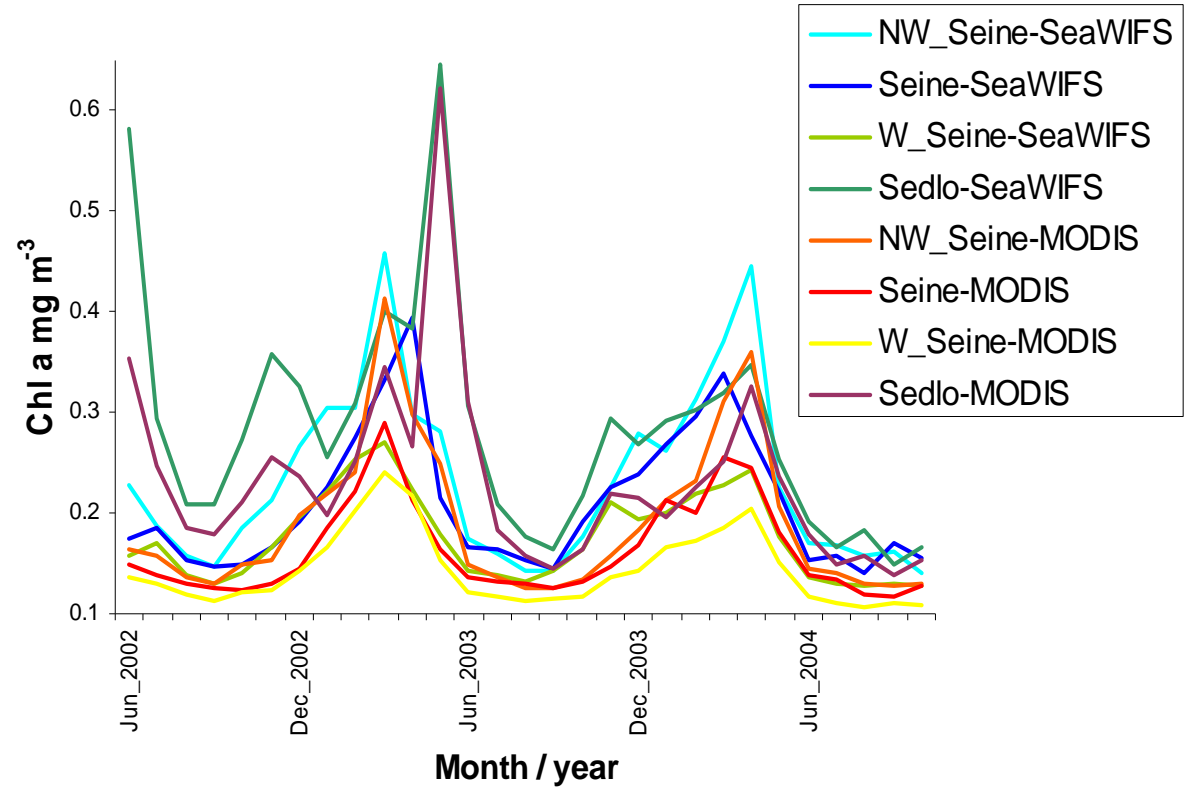

Fig. 11. SeaWiFS and MODIS (2002 to 2004) monthly Chl a averages for northwest Seine (NW_Seine), Seine, west of Seine (W_Seine) and Sedlo areas.

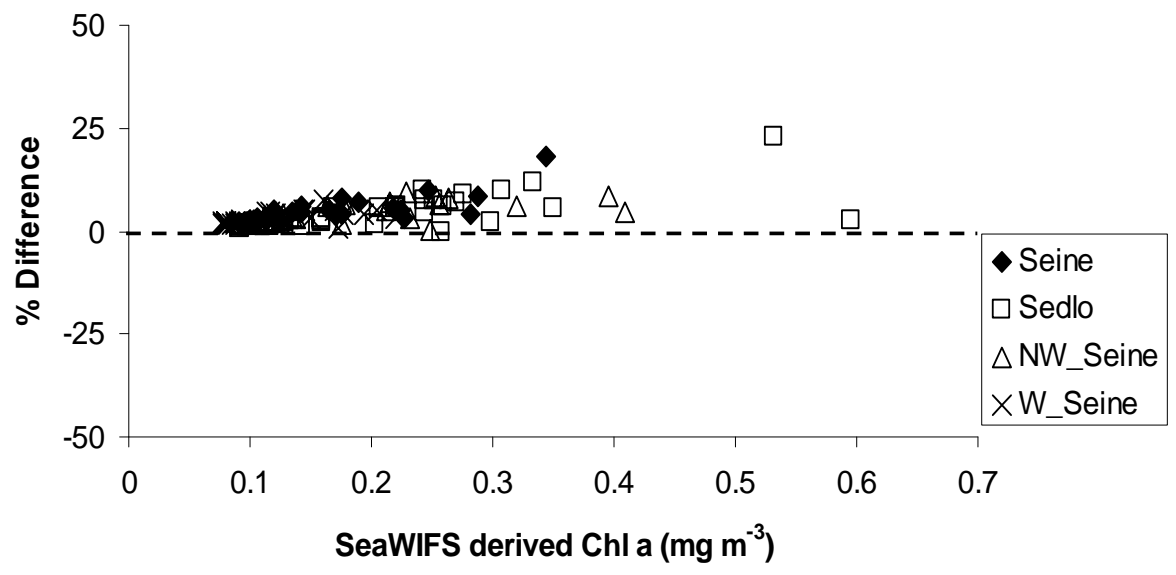

Fig. 12. Percentage differences between SeaWiFS and MODIS monthly means as a function of SeaWiFS derived Chl a monthly means. Percentage values above zero represent SeaWiFS overestimation.

\subsubsection{AVHRR-derived SST}

The AVHRR-derived SST monthly means obtained from 2001 to 2005, for Seine, W_Seine, NW_Seine and Sedlo areas are presented in Fig. 13. A clear seasonal pattern is observed in all 


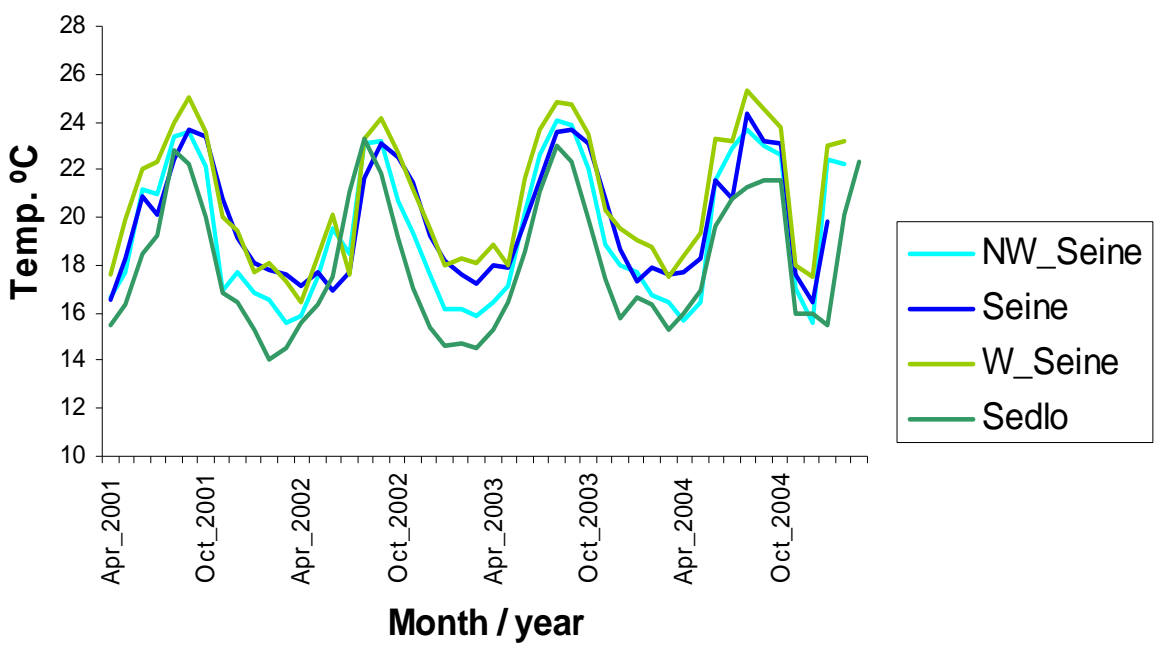

Fig. 13. Monthly SST means obtained through AVHRR images between the years 2001 and 2005, for northwest Seine, (NW_Seine) Seine, west of Seine (W_Seine) and Sedlo.

areas, with higher and lower SST monthly means usually observed during summer and winter months, respectively (cf. Fig. 9 and 10, right images). With decreasing latitude, SST monthly averages begin to rise from February (Sedlo) and March (Seine) on and decrease from August (Sedlo) and September (Seine) on. These results suggest a time lag of about one month for the maximum SST heating/cooling from Sedlo to Seine seamount areas.

For all years, and within a year period, the largest amplitudes are observed during wintertime. Monthly mean SST amplitudes vary approximately from $14^{\circ} \mathrm{C}$ to $24^{\circ} \mathrm{C}$ (Sedlo, with the highest amplitude), $16^{\circ} \mathrm{C}$ to $24^{\circ} \mathrm{C}$ (NW_Seine), $17^{\circ} \mathrm{C}$ to $25^{\circ} \mathrm{C}$ (W_Seine), and $17^{\circ} \mathrm{C}$ to $24^{\circ} \mathrm{C}$ (Seine, lowest amplitude). Sedlo and Seine highest/lowest monthly means are registered during summer/winter 2002 and 2004, respectively.

Inter-annual variability is observed on all four regions (Fig. 14). In general, for all years and areas, AVHRR-SST annual means behave alike. An exception occurs from 2003 to 2004, where Sedlo and Seine means increase while NW_Seine and W_Seine ones decrease. MODIS-SST annual means are not shown since the results obtained from the match-up analyses (see above) showed low correlation with in situ values. 


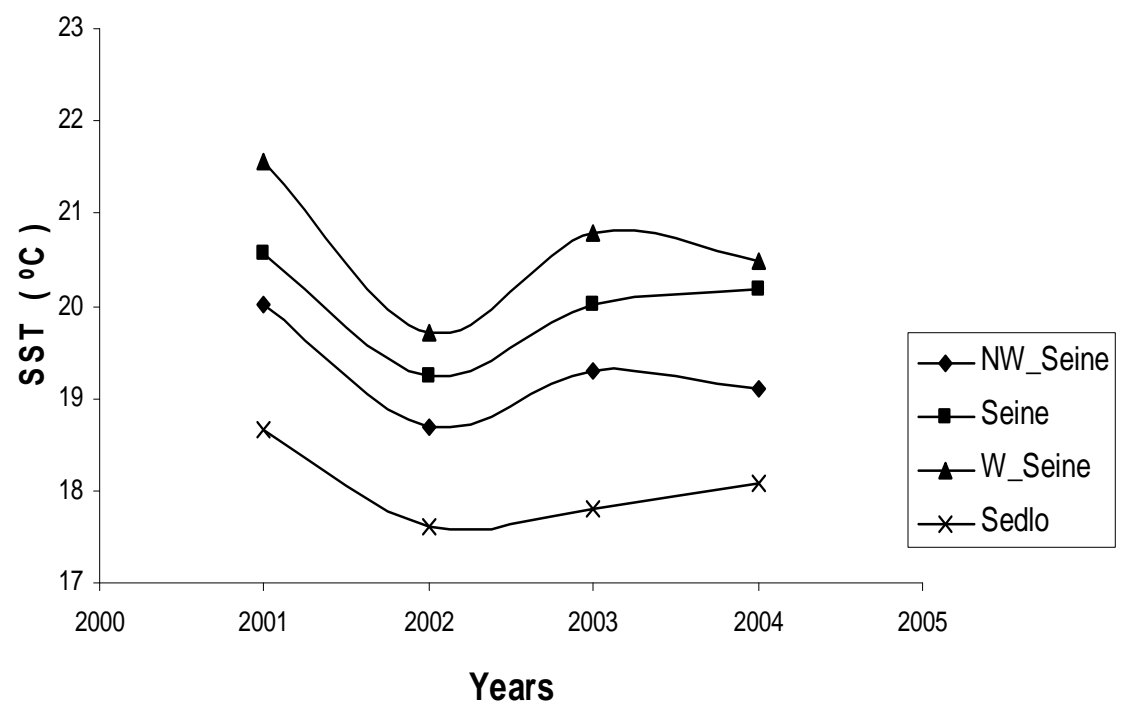

Fig. 14. AVHRR (2001 to 2004) annual SST averages for northwest Seine (NW_Seine), Seine, west of Seine (W_Seine) and Sedlo areas.

For all regions, the highest/lowest AVHRR-SST means occur during 2001 and 2002. Opposite to what was observed with the Chl a annual means, Sedlo has now the lowest annual SST mean, followed by NW_Seine, Seine, and W_Seine areas. In this case, the SST mean difference among the regions is even more noticeable than with the Chl a, clearly highlighting the hypothesis of a mean annual SST variation with latitude.

\section{DISCUSSION}

The Chl a match-up analyses reveal that OC4v4 shows good agreement with the in situ data for Sedlo seamount while for Seine it tends to slightly overestimate the in situ values. OC3M tends to underestimate these for both seamounts. The best algorithm statistical performance was obtained with MODIS data for both seamounts. Our results show that SeaWiFS overestimates $\mathrm{Chl}$ a values in more oligotrophic regions (like Seine) compared with MODIS ones. Small/larger differences between the two sensors are found at low/high Chl a values, respectively. These results are in accordance with Ref. 44 that compared OC4v4 and OC3M algorithms performance, using the same spectral bands (443 and $488 \mathrm{~nm})$ and found the relationship deterministic, with OC3M systematically lower than OC4v4-derived Chl a concentrations by 10 to $20 \%$. Similar results were found in this study with this bias oscillating between 2 to $23 \%$ overestimation of OC4v4-derived Chl a versus OC3M.

SeaWiFS overestimation of in situ values is also reported by other authors for the Atlantic Ocean [12] and for the Mediterranean Sea [43], respectively. However, and conversely to our work, the authors [12] obtained a very high correlation coefficient for this region but also a high RMS error that, according to them, was due to the optical complexity of the region and therefore, divided their region of study into five sub-regions. The eastern portion of the North Central basin (where, by the author's definition, our two seamounts sites should be included) shows better SeaWiFS RMS error (about 29\%) but the lowest sub-region correlation coefficient (0.73) related with the proximity of some stations to the Saharan dust plumes. In our study, SeaWiFS shows lower correlation coefficient values than MODIS ones. Although 
the Ref. 12 had a low number of in situ sampling stations specifically at our study region, our statistical results are within the range of values they obtained. In Ref. 43, the authors justify that OC4v4 is probably more affected by atmospheric corrections problems, because of the multiple band ratio option. In fact, MODIS and SeaWiFS Chl a estimates are subject to errors from atmospheric correction and bio-optical models, which may partially explain the discrepancies found between satellite and in situ data [45]. Sedlo seamount is located within the Azores region, known as an all-year round high overcast region, sometimes affecting satellite valid pixel estimation due to severe cloud cover contamination [17]. Similar atmospheric observations, although less frequent, were reported for Madeira region (near Seine) [46]. Results from Ref.16, using SeaWiFS shows that for open ocean oligotrophic waters and typical atmospheric conditions (maritime aerosols) at a particular pixel the errors in the data products can be as large as about $65 \%$ for Chl a concentrations.

The MODIS underestimation attained in this study is in agreement with the results from the Ref. 44.These showed that the OC3M algorithm tends to underestimate Chl a values below about $1 \mathrm{mg} \mathrm{m}^{-3}$. Our study shows also a systematic increase in MODIS underestimation with increasing $\mathrm{Chl}$ a in situ concentrations, with in situ values that range between 0.01 to $0.44 \mathrm{mg} \mathrm{m}^{-3}$. According to Ref. 44 this OC3M underestimation can probably be related with the fact that OC3M incorporates both 443 and $488 \mathrm{~nm}$ bands and it uses as maximum band ratio, channel $551 \mathrm{~nm}$. The 443-551 ratio is always maximum in low-chlorophyll (blue) waters, but as the chlorophyll concentration increases, reflectance in the $443 \mathrm{~nm}$ band diminishes due to the strong absorption of chlorophyll (and other organic matter) and eventually, the 488-551 ratio becomes the larger ratio [44]. According to these same authors the performance (underestimation) of the OC3M algorithm becomes systematically worse at higher chlorophyll levels $\left(>1 \mathrm{mg} \mathrm{m}^{-3}\right)$. Therefore, best agreement between in situ and MODIS data should be expected in Seine seamount (located about $8^{\circ} \mathrm{S}$ of Sedlo) due to the general decrease in average $\mathrm{Chl}$ a expected at lower latitudes. However, our results apparently show exactly the opposite with higher correlation values between Sedlo in situ and MODIS-derived data. In fact, despite the shift in latitude, Seine is more coastal (about $12{ }^{\circ} \mathrm{E}$ of Sedlo) than Sedlo and therefore, more affected by African coastal processes (e.g. upwelling). Furthermore, the in situ Chl a data over Sedlo presented in this study reports to July and November months, while in Seine, two Spring cruises were also made. What's more, and as previously reported, Seine is more exposed to Sahara dust aerosol plume effects than Sedlo, all of these, justifying the higher mean Chl a in situ values measured in this seamount by [33], and the lower correlation values that we obtained there, between the in situ and MODIS data.

While these results indicate that differences in the two algorithms, OC3M and OC4v4, may contribute to differences in sensor performance, it is a fact that differences in sensor radiometry at common wavelengths contribute more significantly to the quality of $\mathrm{Chl}$ a retrievals, as shown by other authors [47].

Despite the relatively different mean results obtained for MODIS/SeaWiFS (OC) and MODIS/AVHRR (SST) sensors, their variance with time among the two different regions (Sedlo and Seine) is quite similar (Fig. 15). However, it is clear that the highest variation is found with SeaWiFS-OC data with higher CV percentages. 


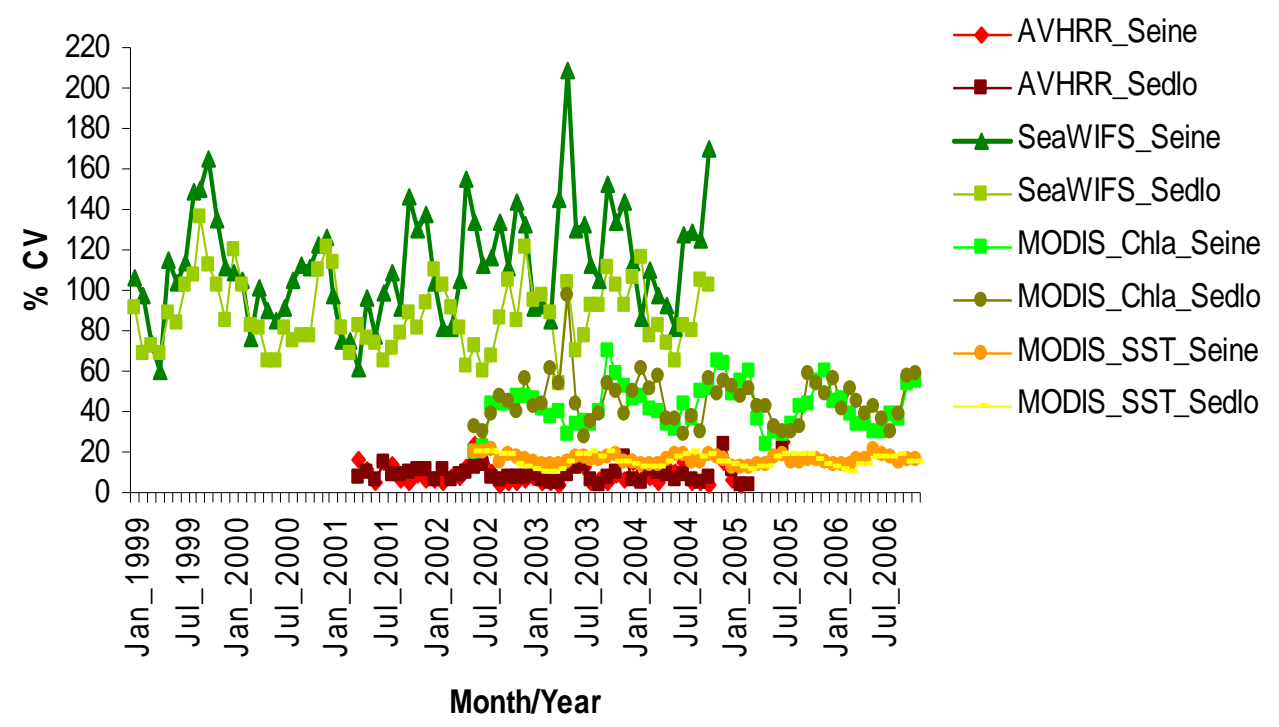

Fig. 15. Monthly Chl a and SST variation (\%CV= variation coefficient percentage) between the years 1999 and 2006 for Sedlo and Seine seamounts.

Nevertheless, same patterns are detected by both satellites (Fig. 16). This makes both OC sensors very useful to analyse near-surface horizontal patterns and variability at medium/large temporal scales.
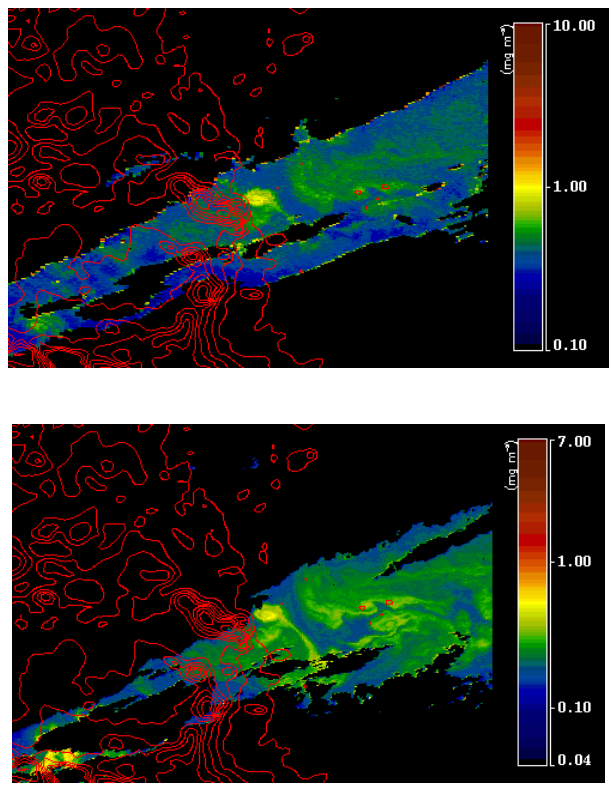

Fig. 16. SeaWiFS (up) and MODIS (down) Chl a (in $\mathrm{mg} \mathrm{m}^{-3}$ ) image over Sedlo on $20^{\text {th }}$ March 2004. The same Chl a near-surface (eddy) structure around Sedlo seamount identified by both sensors. 
Consistent results are found for the SST match-up analyses for Sedlo seamount with the best correlation between in situ surface temperatures and MCSST estimations, being the mean error about $0.9 \%$. Other authors report MCSST mean errors lower than $0.7^{\circ} \mathrm{C}$ [e.g. $17,22-$ 24].

On the other hand, in Seine, low accuracy is found on both algorithms (MCSST and NLSST). This is most probably related with the low number of match-up data points available for Seine, reflected by the lower representation of the actual temperature range in the region. Seasonality strongly impacts skin temperature. In fact, Seine was sampled only in March 2003, and March/April 2004, whereas Sedlo, was sampled during May - August 2001, December 2001 - January 2002, and during July, August and October 2003. The different sampling regimes most probably influenced these results. Even so, the NLSST clearly underestimates the in situ surface temperature values for Seine (showing very low accuracy at high temperatures). In general, both sensors, MODIS-SST and AVHRR-SST show very similar results on both Seine and Sedlo seamounts with CV percentages that range between 3 and 24 (cf. Fig. 15). Specifically, the monthly mean MODIS-SST values for Seine are in general lower than AVHRR-SST ones, nevertheless their variation is slightly higher during the whole period of study. Similar observations were reported for the Azores, Madeira and Canary Islands regions [11]. Acceptable precision in estimation of the SST in the CANIGO region (Canary Islands_Azores_Gibraltar area) with excellent performance at night-time was obtained using other MODIS algorithm: MODIS mid-infrared algorithm (SST4) [19]. This algorithm provides the opportunity to derive more accurate SST fields however, this spectral interval suffers from the contamination of the reflected solar radiation in the daytime, limiting its applicability to night-time or where the risk of solar contamination can be confidently discounted [19].Our match-up analyses need to be improved with more in situ data available for comparison with MODIS-SST and AVHRR-SST data for the NE Atlantic, and in particular, for Seine seamount region. In this study, no attempt was made to separate dayfrom night-time SST imagery neither to differentiate the different NOAA sensors used to estimate AVHRR-SST mean values. Previous results for the Azores region [17] suggest that while day and night-time image histograms must be differentiated, all NOAA sensors data can be merged.

Our results show evident OC and SST seasonal and inter-seamount variability, which is related in part with these parameters latitudinal variability. According to the Ref. 11 this results from a gradual transition from more productive colder and fresher eastern North Atlantic waters to permanently stratified oligotrophic warmer and more saline sub-tropical waters. Sedlo shows a typical mid-latitude seasonality with more pronounced spring phytoplankton blooms and less intense autumn blooms (not evident during all years) and with higher Chl a average values and lower SST average values relative to Seine seamount. Seine spring blooms are less intense, and more time variable (particularly observed in SeaWiFS imagery), generally lower $\mathrm{Chl}$ a and higher SST average values. Sedlo and Seine results suggest a seasonal variation more close to the ones observed by [11] for the Azores and to the Madeira regions, respectively.

As previously reported for the Azores, Madeira, and Canarias regions [11] we also observed an inverse relationship between the OC and SST mean values with lower surface temperature values being generally associated with regions of increased pigment concentrations (e.g. the coldest year 2002 in the four regions of study corresponds to the year with the highest Chl a concentrations). Nevertheless, some exceptions were observed, where low SST values were associated with low OC ones (e.g. year 2004 in Sedlo), most probably resulting from other sources of mesoscale/synoptic variability in the region (e.g. collision of Mediterranean water eddies [35].

This study does not support the idea of increased satellite-derived Chl a biomasses on top of the two seamounts. In fact, although monthly average values can differ, there are no statistically significant differences between MODIS-OC and SeaWiFS-OC monthly averages 
among the four regions of study (two over seamounts and two in far field areas) (e.g. years 2004, 2005 and 2006). The Ref. [38] obtained during 2003 and 2004 OASIS cruises quite constant average integrated $\mathrm{Chl}$ a values on top of both seamounts. Furthermore, historical data (80's) collected by the Portuguese Institute of Marine Research [48-51] within the Seine area report mean Chl a depth integrated values (until 150m) 1,5 below those obtained by [38] for the Seine area during winter and summer months.

The NW_Seine region results show OC and SST values that lie in between the range found for Sedlo and Seine, while the area W_Seine reveals the lowest/highest OC values and SST values, respectively among the four regions of study. This region is located in the Madeira Abyssal Plain with bathymetry values that range between 2500 and $3000 \mathrm{~m}$, and it is considered one of most oligotrophic regions in the North Atlantic.

\section{CONCLUSIONS}

This study constitutes a first attempt to evaluate the performance of two medium resolution $(1.1 \mathrm{~km})$ ocean color (OC) sensors (SeaWiFS and MODIS) and two thermal infrared sensors (AVHRR and MODIS) and also to infer satellite-derived chlorophyll a (Chl a) and sea surface temperature (SST) spatial and temporal variability over Sedlo and Seine seamount regions, located in the NE Atlantic. Previous approaches to characterize these regions in terms of Chl a and SST relied mostly in sporadic in situ sampling and satellite-derived low resolution (i.e. $>4 \mathrm{~km}$ ) global archives.

Results show SeaWiFS overestimation of in situ measured values at more oligotrophic areas such as Seine while MODIS (OC) slightly underestimates these. The best mach-up agreement was obtained on Sedlo seamount with MODIS (OC) and AVHRR (SST) data. Preliminary results show that MODIS (SST) clearly underestimates Seine in situ surface temperature values. However, more in situ data is needed to improve and corroborate these results.

Despite the differences observed between the two OC sensors, the same tendency is found between Chl a satellite estimations and $\mathrm{Chl}$ a in situ measurements and the same patterns are detected by both satellites, making both OC sensors adequate to study patterns and gradients variability at large temporal scales.

Evident seasonal and inter-seamount variability in SST and OC was found in both seamounts. Sedlo shows most of the time typical mid-latitude seasonality with pronounced spring phytoplankton blooms and less intense autumn blooms with higher $\mathrm{Chl}$ a average values and lower SST average values relative to Seine seamount, which demonstrates a more typical tropical variability (of non defined blooms), with generally lower Chl a and higher SST average values.

This study does not support the idea of increased near-surface satellite-derived $\mathrm{Chl}$ a biomasses on top of the two seamounts. As recognized by Ref. 15 the measurements of oligotrophic waters represent only about 5\% of the SeaWiFS Bio-optical Archive and Storage System (SeaBASS) Chl a in situ data. In the nearest future, giving continuity to this study, specific validation cruises are expected, following the consistent and well defined protocols by Ref. 52 and 53, as well as, following the NASA OBPG satellite validation approach described by Ref. 15.

\section{Acknowledgments}

This work was mostly developed and supported through project OASIS, funded by EC (contract EVK3-CT-2002-0073) under the $5^{\text {th }}$ Framework Program. We are grateful at all OASIS team members, through its coordinator, Dr. Bernd Christiansen, for their invaluable professional effort and friendship support along the 3 years of project. We thank crew members of R/V's POSEIDON 295, METEOR M60/1, POSEIDON 309, and RRS DISCOVERY 282, for their important assistance at sea. In particular, we would like to thank 
the following institutions: Universidade dos Açores, Centro do IMAR da Universidade dos Açores; Instituto de Algología Aplicada (ULPGC, Spain); and University of Hamburg (Germany); Direcção de Serviços de Investigação das Pescas da Madeira; Direç̧ão de Serviços de Entrepostos Frigoríficos da Madeira; Direcção Regional da Ciência e Tecnologia dos Açores; Project FISHOR; Octávio Melo, Ana Filipa Silva, Luis Macedo, Sandra Madruga, Patricia Amorim, Sandra Sequeira, Margarida Rodrigues and Paola Castellanos. Partial funding was also provided by projects: RAA-SRAPA-/DRP-DETRA-2000-2003; OPALINA (PDCTE/CTA/49965/2003); Interrreg III-B: ORPAM (03/MAC/4.2/A2); M2.1/I/014/2005: CIMBA, one Post-Doc fellowship (IMAR/DRCT/REF. U\&D/MED.M1.1.2/008/2005//BPD/002/007) and one Doctoral Fellowship (UAç/DRCT/REF. U\&D/MED.M3.1.1/I /003/2005/A). Computer resources and facilities were provided by DOP/UAç, IMAR-DOP/UAç and ULPGC.

\section{References}

[1] M. E. Carr, M. A. M. Friedrichs, M. Schmeltz, M. N. Aita, D. Antoine, K. R. Arrigo, I. Asanuma, O. Aumont, R. Barber, M. Behrefeld, R. Bidigare, E. T. Buitenhuis, J. Campbell, A. Ciotti, H. Dierssen, M. Dowell, J. Dunne, W. Esaias, B. Gentili, W. Gregg, S. Groom, N. Hoepffner, J. Ishizaka, T. Kameda, C. LeQuere, S. Lohrenz, J. Marra, F. Melin, K. Moore, A. Morel, T. E. Reddy, J. Ryan, M. Scardi, T. Smyth, K. Turpie, G. Tilstone, K. Waters, and Y. Yamanaka, "A compariosn of global estimates of marine primary production from ocean color," Deep Sea Res. Pt. II 53, 741-770 (2006) [doi:10.1016/j.dsr2.2006.01.028].

[2] K. R. Turpie and W.E. Esaias, "Sensitivity analysis of MODIS ocean net primary productivity algorithms using SeaWiFS data," presented at 2004 Ocean Sci. Meet., Abstract OS22A-05, AGU, Portland, OR, (2004).

[3] S. J. Weeks, F. A Shillington, and G. B. Brundrit, "Seasonal and spatial SST variability in the Agulhas retroflection and Agulhas return current," Deep Sea Res. Pt. I 45 (10), 1611-1625 (1998) [doi:10.1016/S0967-0637(98)00036-3].

[4] N. Kabbara, X.-H Yan, V. V. Klemas, and J. Pan., "Temporal and spatial variability of the surface temperature anomaly in the Levantine Basin of the Eastern Mediterranean," Int. J. Rem. Sens. 23(18), 3745-3761 (2002) [doi:10.1080/01431160110070663].

[5] A. Tejera, L. García-Weil, K. J. Heywood, and M. Cantón-Garbín, "Observations of oceanic mesoscale features and variability in the Canary Islands area from ERS-1 altimeter data, satellite infrared imagery and hydrographic measurements," Int. J. Rem. Sens. 23(22), 4897-4916(2002) [doi:10.1080/01431160110034681].

[6] J. M. Vargas, J. Garca-Lafuente, J. Delgado, and F. Criado, "Seasonal and windinduced variability of sea surface temperature patterns in the Gulf of Cadiz," J. Mar. Syst. 38, 205-219(2003) [doi:10.1016/S0924-7963(02)00240-3].

[7] I. Bashmachnikov, V. Lafon, and A. Martins, "Sea surface temperature distribution in the Azores region. Part: II: Space-time variability and underlying mechanisms," Arquipélago Life Marine Sci. 21(A), 19-32 (2004).

[8] A. Martins and J. L. Pelegrí, "CZCS chlorophyll patterns in the South Atlantic Bight during low vertical stratification conditions," Cont. Shelf Res. 26, 429-457 (2006) [doi:10.1016/j.csr.2005.11.012].

[9] R. I. Crocker, D. K. Matthews, W. J. Emery, and D. G. Baldwin, "Computing coastal ocean surface currents from infrared and ocean color satellite imagery," IEEE Trans. Geosci. Rem. Sens. 45(2), 435-447 (2007) [doi:10.1109/TGRS.2006.883461].

[10] M. Kahru, B. G. Mitchell, S. T. Gille, C. D. Hewes, and O. Holm-Hansen, "Eddies enhance biological production in the Weddell-Scotia confluence of the Southern Ocean," Geophys. Res. Lett. 34, L14603 (2007) [doi:10.1029/2007GL030430]. 
[11] A. M. Martins, A. S. B. Amorim, M. P. Figueiredoc, R. J. Sousa, A. Mendonça, I.Bashmachnikovb, and D. S. Carvalho, "Sea Surface Temperature (AVHRR, MODIS) and Ocean Colour (MODIS) seasonal and interannual variability in the Macaronesian islands of Azores, Madeira, and Canaries," Proc. SPIE 6743, 67430A1-67430A15 (2007). [doi:10.1117/12.738373].

[12] W. W. Gregg and N. W. Casey, "Global and regional evaluation of the SeaWiFS chlorophyll data set," Rem, Sens. Environ. 93, 463-479 (2004) [doi:10.1016/j.rse.2003.12.012].

[13] C. Fuentes-Yaco, E. Devred, S. Sathyendranath, T. Platt, L. Payzant, C. Caverhill, C. Porter, H. Maass, and N. George, "Comparison of in situ and remotely-sensed chlorophyll-a in the Northwest Atlantic," Indian J. Mar. Sci. 34 (4), 341-355 (2005).

[14] R. Davenport, S. Never, P. Helmke, J. Perez-Moreno, and O. Llinás, "Primary productivity in the northern Canary Islands region as inferred from SeaWiFS imagery," Deep. Sea. Res. Pt II 49, $3481-3496$ (2002) [doi:10.1016/S09670645(02)00095-4].

[15] S. W. Bailey and P. J. Werdell, "A multi-sensor approach for the on-orbit validation of ocean color satellite data products," Rem. Sens. Environ. 102, 12-23 (2006) [doi:10.1016/j.rse.2006.01.015].

[16] C. Hu, K. L. Carder, and F. E. Muller-Karger, "How precise are SeaWiFS ocean color estimates? Implications of digitization-noise errors," Rem. Sens. Environ. 76, 239-249 (2001) [doi:10.1016/S0034-4257(00)00206-6].

[17] Lafon, V., A. Martins, M. Figueiredo, M.A. Melo Rodrigues, I. Bashmachnikov, A. Mendonça, L. Macedo and N. Goulart, "Sea surface temperature distribution in the Azores region. Part: I: AVHRR imagery and in situ data processing," Arquipélago Life Marine Sci. 21(A), 1-18 (2004).

[18] F. Eugenio, J. Marcello, A. Hernández-Guerra, and E. Rovaris, "Methodology to obtain accurate sea surface temperature from locally received NOAA-14 data in the Canary-Azores-Gibraltar area," Sci. Mar. 65(Suppl.1): 127-137 (2001).

[19] J. Marcello, F. Eugenio, and A. Hernandez, "Validation of MODIS and AVHRR/3 Sea Surface Temperature Retrieval Algorithms," Int. Geosci. Rem. Sens. Symp. 2, 839-842 (2004).

[20] R. L. Bernstein, "Sea surface temperature estimation using the NOAA 6 satellite advanced very high resolution radiometer," J. Geophys. Res. 87, 9455-9465(1982).

[21] E. P. McLain, W. G. Pichel, and C. C. Walton, "Comparative performance of AVHRR based multichannel sea surface temperatures over the ocean," Mon. Weather Rev. 112, 303-313 (1985).

[22] O. B. Brown, J. W. Brown, and R. H. Evans, "Calibration of advanced very high resolution radiometer infrared observations," J. Geophys. Res. 90, 11667-11678 (1985).

[23] P. J. Minnett, "Consequences of sea surface temperature variability on the validation and applications of satellite measurements," J. Geophys. Res. 96(C10), 18475-18489 (1991).

[24] H. Kawamura, Y. Kawai, and J. Barton, "Characteristics of the AVHRR-derived Sea Surface Temperature in the oceans around Japan," J. Geophys. Res. 100, 8777-8790 (1995).

[25] J. Dower, H. Freeland, and K. Juniper, "A strong biological response to oceanic flow past Cobb Seamount," Deep Sea Res. Pt. II 39, 1139-1145(1992) [doi:10.1016/01980149(92)90061-W].

[26] A. Genin and G. W. Boehlert, "Dynamics of temperature and chlorophyll structures above a seamount: an oceanic experiment," J. Mar. Res. 43, 907-924 (1985)

[27] L. A. Comeau, A. F. Vézina, M. Bourgeois, and S. K. Juniper, "Relationship between phytoplankton production and the physical structure of the water column 
near Cobb Seamount, northeast Pacific," Deep. Sea Res. Pt. I 42, 993-1005 (1995) [doi:10.1016/0967-0637(95)00050-G].

[28] K. Furuya, T. Odate, and K. Taguchi, "Effects of a seamount on phytoplankton production in the western Pacific Ocean," in Biogeochemical Processes and Ocean Flux in the Western Pacific, H. Sakai and Y. Nozaki, Eds., pp. 255-273, Tokyo (1995).

[29] B. Mourino, E. Fernández, P. Serret, D. Harbour, B. Sinha, and R. Pingree, "Variability and seasonality of physical and biological fields at the Great Meteor Tablemount (subtropical NE Atlantic)," Oceanol. Acta 24 (2), 1-20 (2001) [doi:10.1016/S0399-1784(00)01138-5].

[30] E. P. McClain, W. G. Pichel, and C. C. Walton, "Comparative performance AVHRR-based multichannel sea sur-face temperatures," J. Geophys. Res. 90, 1158711601 (1985).

[31] J. E. O'Reilly, S. Maritorena, D. Siegel, M. C. O'Brien, D. Toole, B. G. Mitchell, M. Kahru, F. P. Chavez, P. Strutton, G. Cota, S. B. Hooker, C. R. McClain, K. L. Carder, F. Muller-Karger, L. Harding, A. Magnuson, D. Phinney, G. F. Moore, J. Aiken, K. R. Arrigo, R. Letelier, and M. Culver, "Ocean color chlorophyll a algorithms for SeaWiFS, OC2, and OC4: Version 4," 11, NASA Goddard Space Flight Center , 9-23, Greenbelt, Maryland (2000).

[32] C. C. Walton, W. G. Pichel and J. F. Sapper, "The development and operational application of nonlinear algorithms for the measurements of sea surface temperatures with the NOAA polar-orbiting environmental satellites," J. Geophys. Res. 103, 27999-28012 (1998) [doi:10.1029/98JC02370].

[33] A. Longhurst, S. Sathyendranath, T. Platt, and C. Caverhill, "An estimate of global primary production in the ocean from satellite radiometer data," J. Plankton Res. 17, 1245-1271(1995) [doi:10.1093/plankt/17.6.1245].

[34] Universität Hamburg, National University of Ireland, Galway, IMAR -Instituto do Mar, University of Liverpool, Universidad de Las Palmas de Gran Canaria, Universität Rostock, National Environment Research Council, World Wide Fund for Nature, and Friedrich-Alexander-Universität Erlangen, "Oceanic Seamounts: an integrated study (OASIS) - OASIS Final Scientific and Technical Report (for the period 01.12.2002-30.11.2005)," Universität Hamburg, Hamburg, 1-80 (2006).

[35] I. Baschmachnikov, M. White, C. Mohn, A. Martins, J. L. Pelegrí, and F. Machín, "Mediterranean water eddies interaction with Sedlo and Seine seamounts, Subtropical North-East Atlantic" Deep. Sea. Res. Pt. II 56, 2593-2605 (2009) [doi:10.1016/j.dsr2.2008.12.036]

[36] A. Martins, M. Figueiredo, P. Castellanos, A. Mendonça, L. Macedo, and M. MeloRodrigues, "DETRA - a new remote sensing project for the Northeast Atlantic" presented at Taller y Tertulia en Oceanografía, Congreso Interdisciplinar en Ciencias del Mar, 2001, Universidad de Vigo, Vigo, Spain.

[37] M. Figueiredo, A. Martins, P. O. Castellanos, A. Mendonça, L. Macedo, M. Rodrigues, V. Lafon, and N. Goulart, "HAZO- A software package for automated AVHRR and SeaWiFS acquisition and processing," 3, Departamento de Oceanografia e Pescas da Universidade dos Açores, Horta, Spain (2004).

[38] J. Arístegui, A. Mendonça, J. C. Vilas, M. Espino, I. Polo, M. F. Montero, and A. Martins, "Plankton metabolic balance at two north Atlantic seamounts," Deep Sea Res. Pt. II 56 (25), 2646-2655 (2009) [doi: doi:10.1016/j.dsr2.2008.12.025].

[39] H. R. Gordon and D. K. Clark, "Remote sensing optical properties of a stratified ocean: an improved interpretation," Appl. Opt. 19, 3428-3430 (1980).

[40] S. Sathyendranath and T. Platt, "Remote sensing of ocean chlorophyll: consequence of nonuniform pigment profile," Appl. Opt. 28, 490-495 (1989). 
[41] J. R. V. Zaneveld, A. H. Barnard, and E. Boss, "Theoretical derivation of the depth average of remotely sensed optical parameters," Opt. Exp. 13, 9052-9061 (2005) [doi:10.1364/OPEX.13.009052].

[42] SatCmp -computer program (version: 0.1), Centro do IMAR da Universidade dos Açores, Horta, Spain (2006).

[43] F. D’Ortenzio, S. Marullo, M. Ragni, M. Ribera d'Alcala', and R. Santoleri, "Validation of empirical SeaWiFS algorithms for chlorophyll-a retrieval in the Mediterranean Sea: A case study for oligotrophic seas," Rem. Sens. Environ. 82, 7994 (2002) [doi:10.1016/S0034-4257(02)00026-3].

[44] J. W. Campbell, "Development of algorithms and strategies for monitoring chlorophyll and primary productivity in coastal ocean, estuarine and inland water ecosystems," Final Technical Report NAS5-96063, pp. 1-20, University of New Hampshire, Durham, NH (2003).

[45] C. Zhang, C. Hu, S. Shang, F. E. Müller-Karger, Y. Li, M. Dai, B. Huang, X. Ning, and H. Hong, "Bridging between SeaWiFS and MODIS for continuity of chlorophyll-a concentration assessments off Southeastern China," Rem. Sens. Environ. 102, 250-263 (2006) [doi:10.1016/j.rse.2006.02.015].

[46] R. M. A.Caldeira, S. Groom, P. Miller, D. Pilgrim, and N. P. Nezlin, "Sea-surface signatures of the island mass effect phenomena around Madeira Island, Northeast Atlantic," Rem. Sens. Environ. 80, 336-360 (2002) [doi:10.1016/S00344257(01)00316-9].

[47] B. A. Franz, P. J. Werdell, G. Meister, S. W. Bailey, R. E. Eplee, Jr., G. C. Feldman, E. J. Kwiatkowska, C. R. McClain, F. S. Patt, and D. Thomas, "The continuity of ocean color measurements from SeaWiFS to MODIS," Proc. SPIE 5882, 304-316 (2005) [doi:10.1117/12.620069].

[48] INIP, "Programa de Apoio as Pescas na Madeira-II cruzeiro de Reconhecimento de Pesca e Oceanografia 020241180," 11, INIP Ed., Lisboa, 1-220 (1982).

[49] INIP, "Programa de Apoio as Pescas na Madeira-III cruzeiro de Reconhecimento de Pesca e Oceanografia 020330981," 22, INIP Ed, Lisboa, 1-124 (1984a).

[50] INIP, "Programa de Apoio as Pescas na Madeira-IV cruzeiro de Reconhecimento de Pesca e Oceanografia 020390582," 3, INIP Ed, Lisboa, 1-120 (1984b).

[51] INIP, "Programa de Apoio as Pescas na Madeira-V cruzeiro de Reconhecimento de Pesca e Oceanografia 020451182," 31, INIP Ed, Lisboa, 1-124, (1984c).

[52] J. L. Mueller, R. W. Austin, A. Morel, G. S. Fargion, and C. R. McClain, "Ocean optics protocols for satellite ocean color sensor validation: Revision 4. Introduction, background and conventions," NASA Tech. Memo, vol. 2003-21621, National Aeronautics and Space Administration, Goddard Space Flight Center, Greenbelt, MD (2003a).

[53] J. L. Mueller, C. Pietras, S. Hooker, R. W. Austin, M. Miller, K. D. Knobelspiesse, R. Frouin, B. N. Holben, and K. Voss, "Ocean optics protocols for satellite ocean color sensor validation: Revision 4. Instrument specifications, characterization and calibration," NASA Tech. Memo, vol. 2003-21621, National Aeronautics and Space Administration, Goddard Space Flight Center, Greenbelt, MD (2003b). 